Housing Studies,

Vol. 20, No. 6, 897-929, November 2005

Routledge

\title{
Favoured Owners, Neglected Tenants: Privatisation of State Owned Housing in Hanoi
}

\author{
HOAI ANH TRAN \& ELISABETH DALHOLM \\ Department of Architecture, Lund University, Sweden
}

(Received March 2004; revised March 2005)

\begin{abstract}
This paper presents selected findings from the project 'Privatisation of public housing in Hanoi, the impacts on housing quality and social equality' which was financed by the Swedish International Development Authority (SIDA). The project analyses the consequences of privatisation on the housing conditions of those tenants and owners who live in privatised and partly privatised multi-family apartment buildings. This paper focuses on the consequences of privatisation on the housing and living conditions of tenants compared to those of owners, and presents findings. The paper concludes that privatisation actually helps to strengthen the existing inequity between different social groups, in the sense that the privatisation policy supports senior government officials, many of whom are well situated both financially and socially, and ignores poor and lowincome households. Privatisation also contributes to enhancing the inequality between better-off housing areas and poorer ones. Mixed ownership, and the lack of regulations about the duties and rights of owners and tenants after privatisation, also lead to serious degradation of common areas in all residential blocks.
\end{abstract}

KEY WoRDS: Housing privatisation, apartment buildings, homeownership

\section{Democratisation or Segregation: The Discourses of Housing Privatisation}

Over the last two decades, privatisation has been a significant trend in housing delivery in many countries. Privatisation is presented as a measure to liberalise housing markets, increase productivity and efficiency, and extend consumer choice and influence (Linneman et al., 1994). It is considered to be a key ingredient in the decentralisation and democratisation process, and its implementation leads to the withdrawal of government intervention, giving more freedom and authority to communities, groups and individuals to enable investment in housing (Clapham, 1995; La Grange, 1998; Zhang, 1999). It is presented as a means to rationalise subsidies and enhance equitable distribution of resources (Linneman et al., 1994; La Grange, 1998). In contrast, public rental housing is presented as a form of housing administration and management that involves too much

Correspondence Address: Hoai Anh Tran, Department of Architecture, Lund University, Box 221 00, Lund, Sweden. Email: hoai_anh.tran@arkitektur.lth.se

ISSN 0267-3037 Print/1466-1810 Online/05/060897-33 (C) 2005 Taylor \& Francis

DOI: $10.1080 / 02673030500291066$ 
state intervention, burdens the state budget and does not effectively mobilise private resources. In many countries, the sale of public housing stock is a common privatisation method.

The privatisation discourse is very much a discourse about homeownership. Ownership creates incentives and affects behaviour management (Clapham, 1995; Vickers \& Yarrow, 1990, in Linneman et al., 1994). Ownership is expected to lead to better housing quality and better management. However, discussions vary greatly regarding the consequences of the sale of public housing stock to low-income people. Proponents argue that public housing ownership permits low-income tenants to gain access to an important vehicle for savings and wealth accumulation. Opponents argue against these so-called 'financial benefits'. Many studies found that the sale of public housing leads to a process of segregation within which tenants are discriminated against (Chan, 2000; Clapham, 1995; Jaffe et al., 1995; Lee, 2000; Logan et al., 1999; Stanovnik, 1994; Zhang, 1999; Zhou \& Logan, 1996).

Many studies also argue that the sale of public housing leads to a process of 'residualisation', in which the best housing units and highest income tenants are removed from public housing, leaving low-income tenants with the poorer units (Chan, 2000; Clapham, 1995; Linneman et al., 1994; Stanovnik, 1994; Whitehead, 1993; Zhang, 1999). In the Czech Republic, privatisation and the deregulated housing market is considered to lead to increasing socio-spatial disparities, such as the concentration of a well-educated and high income population in some parts of the city, and the concentration of manual workers and people with lower education levels in other parts (Sýkora, 1999). It also results in a gentrification process whereby neighbourhoods are renovated by the wealthy people who move there, replacing lower income people who move out to less attractive areas.

The issue of whether or not homeownership equals empowerment, and the impact of this process on social equality, is taken up by many studies. Some argue that owners are empowered, while tenants are disempowered through processes of social exclusion. According to King (1996) the emphasis on homeownership is a source of inequality exclusion (Gurney, 1999) since it gives owners more freedom and opportunities while imposing limitations on tenants, who are treated as not being capable of taking responsibility for their dwellings. A similar argument is put forward by Gurney (1999). When ownership is promoted as a 'normal form' of housing, as in the UK, it leads to a distinction between owners and renters. This distinction implies a prejudice against non-owners who then become a stigmatised social group, thus creating new forms of social exclusion.

\section{Privatisation and Inequality}

Why do some dwellers become owners and others not? This paper takes up the issue of state subvention of homeownership and deals with the questions of who obtains the most benefits, who is left out and whether this is fair.

Studies on privatisation in China (Lee, 2000, 2002; Zhao \& Bourassa, 2003) found that housing reform and privatisation created opportunities and benefits for those who were better located on the social ladder under the old regime. This meant that the urban masses at the bottom of the work hierarchy, and those with a less favourable set of hierarchical relationships, were left to live in poor conditions. Lee argues that this system favours the protection of existing distributional benefits while victimising those who have only recently joined the workforce. Zhao \& Bourassa (2003) point out that when privatisation 
reinforces rather than removes the role of the work units in housing provision, it leads to the increase of horizontal inequity between powerful and poorer work units, and further worsens housing inequity among employees.

In a study of the privatisation of public housing in Zambia, Schlyter (2002) puts forward a similar argument. According to Schlyter, this process favoured sitting tenants, who had already enjoyed the advantages of living in more secured forms of tenure, while ignoring other social groups. This affected younger civil servants who could no longer obtain staff houses and could not afford a private house.

Chan (2000) discusses the process of public housing privatisation and the promotion of homeownership in Hong Kong that resulted in an increase in real estate speculation, benefiting big investors and affluent owners, and making life more difficult for tenants in public housing. Chan argues that the process contributed to widening the gap between rich and poor, owners and non-owners, men and women, and between residents of different generations.

The author speculated on how this situation compares to Hanoi, where privatisation is being carried out within a transformation process from a state-planned to a market oriented economy, similar to the situation in China. This paper explores the specific situation in Hanoi, including that of tenants and owners, and the circumstances around their tenure situation.

\section{Background}

\section{State Funded Housing Provision}

This study deals with the privatisation of a specific part of state owned housing stock: the multi-family residential blocks. The City of Hanoi owns 450 such buildings of four to five storeys each, concentrated in 24 housing areas and providing a total living area of 1 million $\mathrm{m}^{2}$ for a population of approximately 140000 .

The blocks were built during the 1960s to 1980 s, when housing production, especially in the cities, was under a state monopoly. The state (and its institutions) was responsible for the planning, design and construction of these areas. There was no alternative housing. Private individuals were not allowed to build their own houses.

These areas could by no means be considered 'social housing'. They were intended exclusively for state employees, allocated on the basis of rank and duration of employment. Housing, together with other everyday life necessities, such as food and clothing, was provided by the state to its employees as part of their salary-a payment in kind. People in the private sector were excluded from this system.

Employees were placed in a housing queue and, as the number of apartments produced was never sufficient, the waiting time could be up to between 10 and 15 years. The allocation standard was 4 to $5 \mathrm{~m}^{2}$ per person. A family of four could be allocated 18 to $24 \mathrm{~m}^{2}$. High-ranking officials had priority in the queue and were allocated more living space. Low-ranking employees without children were allocated less living space. As the housing shortage was acute, it was commonplace for an apartment of 20 to $24 \mathrm{~m}^{2}$ to be shared between two households. Since employees of different ranks belonging to one work place were usually placed in the same area, there was a mix of social groups in these areas.

The state, via the work places, had ultimate rights in housing distribution, transfer and alienation. Tenants could not influence the allocation decision. However, tenants were 
given long-term rights of occupancy and could even leave the right of occupancy to their children. This remains the case today.

In this system, to work for a state institution is the most certain way to secure housing. However, not all state institutions have the capacity to provide housing for their employees. 'Strong' work places, such as the Ministry of Police, Ministry of Construction, and other powerful ministries, can provide more (and better quality) housing while 'weak' work places, such as secondary schools, small factories and enterprises, hardly own any housing at all.

Apart from housing that belongs to different state institutions, a good part of the state owned housing stock in Hanoi belongs directly to the City of Hanoi, a large (and powerful) institution with many subordinate departments. Funds for housing come from state budgets, national or municipal, following the national economic plans. As Hanoi is the capital, municipal funding was often national funding and many allocation decisions took place at municipal level. The exchange and transfer of housing among the subordinate departments was not uncommon. In the 1990s, when privatisation was implemented, the areas belonging to these departments were transferred to the control of the city housing authority. To date, this transfer is still ongoing.

For many years, these multi-family residential blocks were the only housing type built in the cities, except for the construction of so-called 'temporary housing' by private individuals or groups. Under the slogan 'socialist housing for the modern, socialist person', apartments in these areas were considered modern and superior to the old house types. To have an apartment like this indicated obvious financial benefits, as well as a public affirmation of achievement. However, as the apartment blocks became gradually degraded due to mismanagement and neglect, they lost their modern and superior status. Once economic reform, privatisation, and the boom of private housing in the 1990s was established, they became a symbol for the failure of socialist housing.

\section{State Planned Housing Areas}

The majority of housing areas were planned according to Soviet principles. They comprised standard units of residential and associated facilities, such as kindergartens and department stores, and were based on a fixed population formula, usually from 7000 to 15000 people in an area of 15 to $25 \mathrm{ha}$. Smaller housing areas were less than $10 \mathrm{ha}$, and these were built without comprehensive plans.

The blocks consisted of monotonous designs with simple rectilinear lines, totally alike and only distinguishable from one another by code-like numbering such as A3 or D6 (Figure 1). The apartments were designed in groups of 'prototypes'. There were few variations in the layout and size of apartments in one block. In blocks of the same period the apartments are usually identical (Figure 2).

\section{Housing Regulations and Practices: Existing Inequality}

During the 1960s to the late 1980s, housing was part of a welfare policy that supported state employees, so rents were set very low. In fact, the rent was quite insignificant compared to income, and at far too low a level for appropriate maintenance to take place. The result was that very little maintenance work was undertaken during these years and the areas degraded quickly. Since the start of privatisation, rent has been adjusted several 


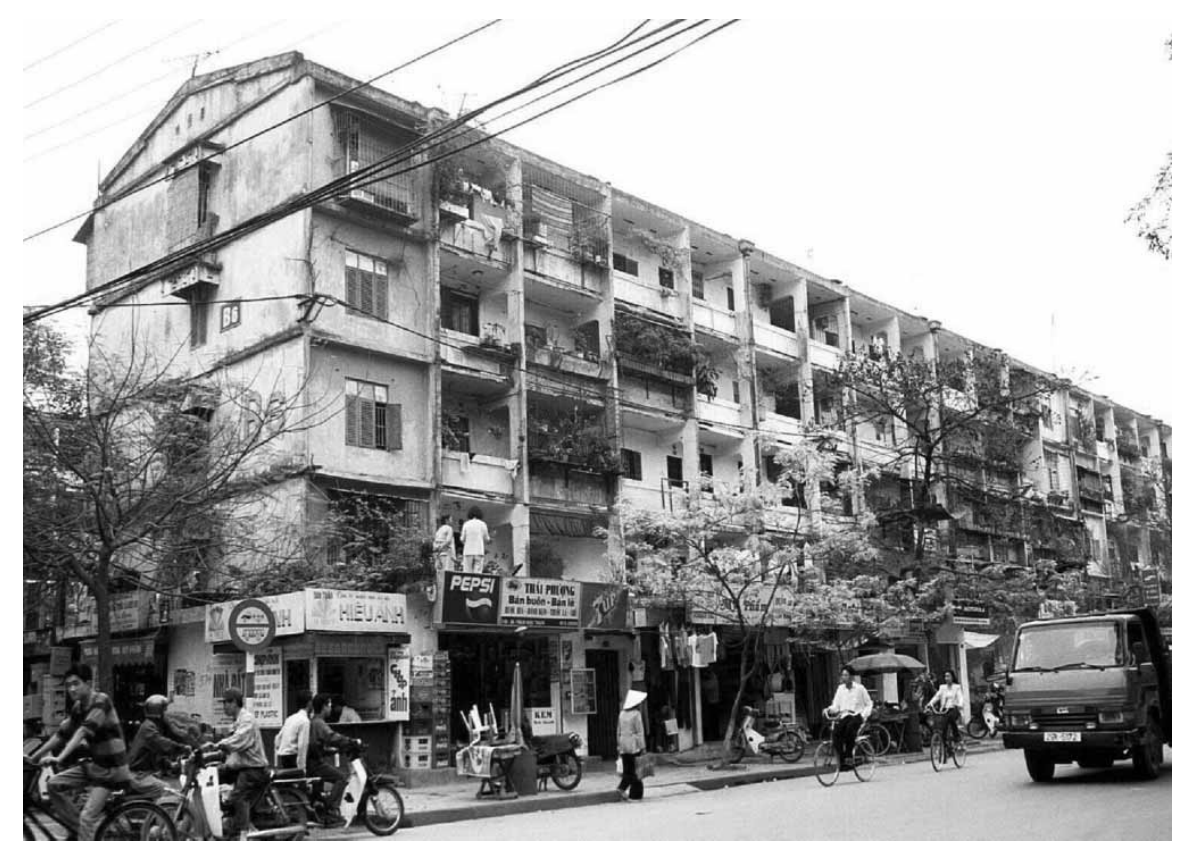

Figure 1. All blocks are of the same monotonous design

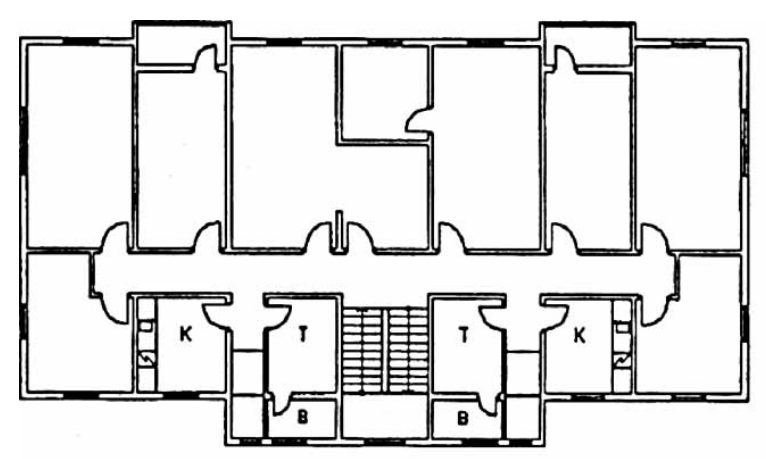

B: bathroom

K: kitchen

T: toilet

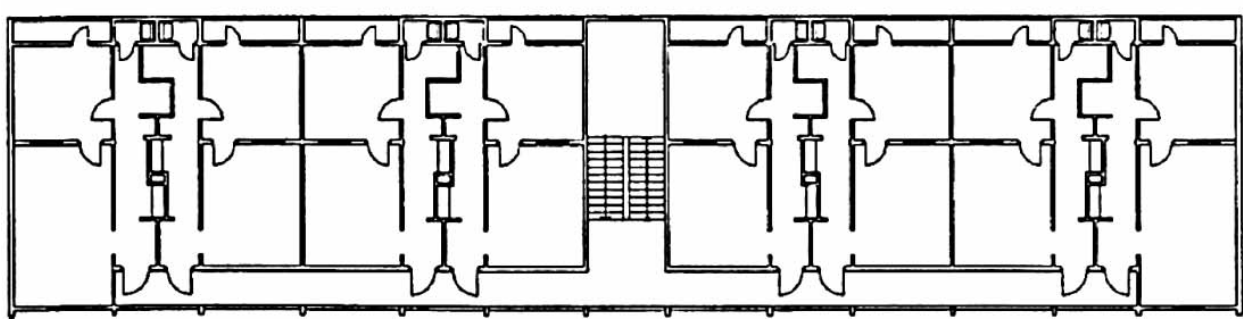

Figure 2. Some typical layouts of blocks built during the 1960s and 1970s 
times and has gradually increased to the present figure of $50000 \mathrm{VND}$ per standard apartment $\left(24 \mathrm{~m}^{2}\right)$ per month, about 10 per cent of the official salary of a young state employee at the beginning of his/her career, or 2.5 per cent of this person's income. ${ }^{1}$

With no clear regulations specifying how the buildings should be maintained, and no legislations on the rights and duties of tenants and housing authorities, a chaotic situation prevailed. The housing authorities could operate wholly from their own perspective and according to their own plan, paying little attention to tenants' wishes. When it was necessary for something to be repaired, tenants could report this to the housing authorities, who would take action or not, depending on whether this fitted into their plan and budget. Tenants had no organisation to which they could turn when they had complaints about the housing authorities. The lack of maintenance has been a major cause of tenants' discontent, and the source of many conflicts between tenants and authorities. Many tenants responded to the neglect of the building by not paying the rent.

On the other hand, the housing authorities had no legal support to deal with violations by tenants. They could not even evict the tenants who did not pay rent for many years; neither could they do much to stop violations such as private construction activities that had the potential to damage the blocks.

One of the most common problems in these areas was private construction activity by tenants. Despite restrictions on tenants with regard to changes to the apartments and the use of public space adjacent to the blocks, the level of overcrowding was such that the majority of tenants were defiant of the rules and tried all possible ways to add space to their apartments: at the balconies (for those who lived on the upper floors), and on the public ground in front and behind their apartments (for those who lived on the ground floor). Tenants were fined for these illegal constructions, but they were usually tolerated. They added a significant weight load to the blocks and, in many cases they make the blocks quite dangerous to live in (Figure 3).

Although apartments were state owned and could not really be sold, the sale of the "useright' was common. This means that the rightful tenants (state employees who obtained their apartments from their work places) sold their right to use the apartment to others. These others could be state employees from some poorer state institutions who were not provided with state housing. They could also be people who worked in the private sector. Before privatisation this type of transaction was the main factor that brought people from the private sector into these areas, contributing to the diversification of the population structure.

In the 1970s and early 1980s, when this sale was not legal or accepted, those who bought the use-right from the original tenants lived in a constant state of insecurity about their housing, facing the threat of eviction from the local authority. However, by the end of the 1980s this type of transaction was widespread and eventually legalised. From this time, tenants could apply to the local authority and to the housing company to sell the use-right to another person. A fee would be paid and the transaction formally approved.

Private individuals who bought the use-right of a state owned apartment from a tenant had to pay what was considered to be the market price of the use right. With privatisation, this price has greatly increased and is very close to the apartment's market price.

Therefore, there were different categories of tenants in these areas: state employees who obtained their apartment from their own institutions, people who bought the use-right from the original tenants, and tenants who rented second-hand from the original tenants. Both the original tenants, and the tenants who bought the use-right, have long-term rights of 

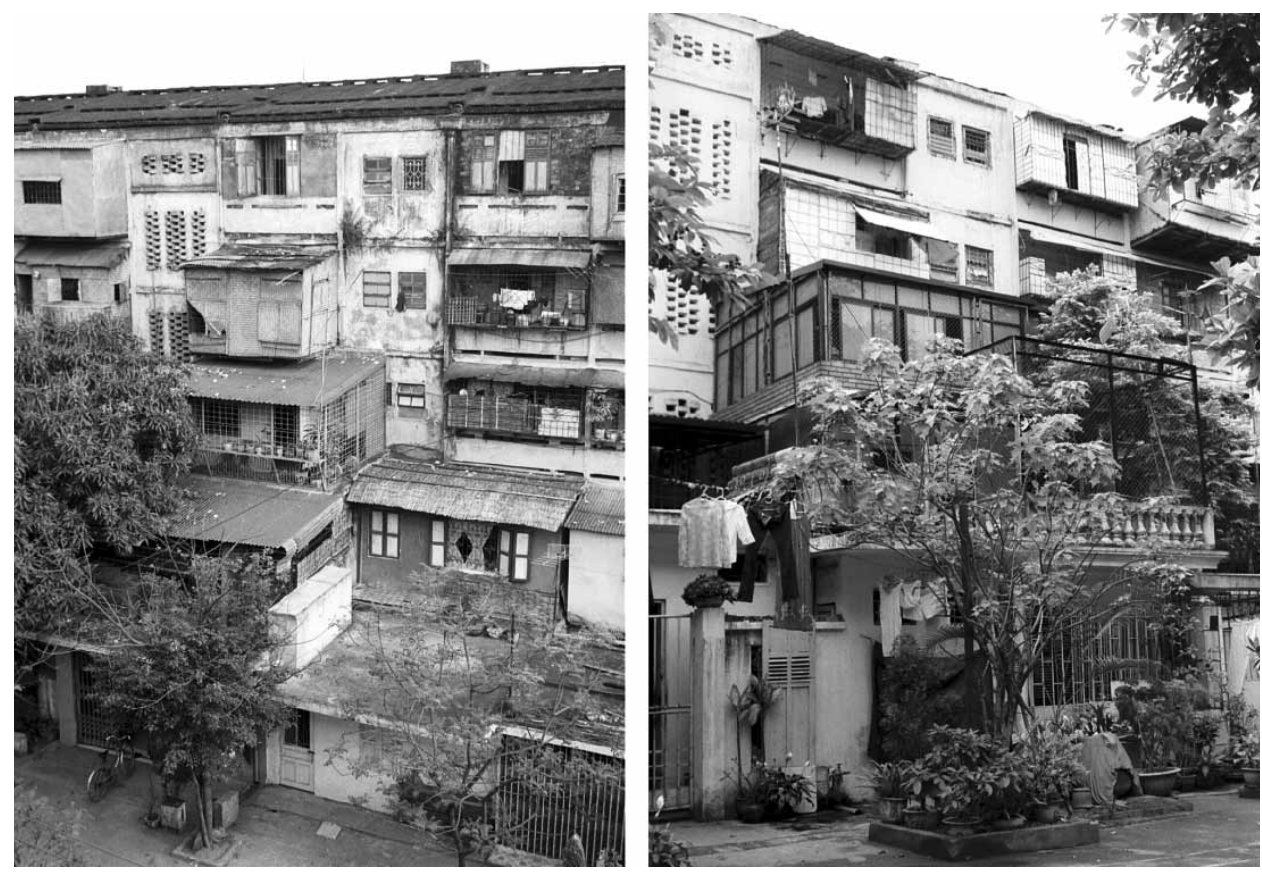

Figure 3. A common violation was the construction of an extension by individual tenants in order to increase their living space

occupancy and have the right to purchase ownership when apartments are privatised. Tenants who rent second-hand have only short-term rights of occupancy and no rights to purchase.

\section{Privatisation Policy}

In Vietnam, the sale of state owned housing stock began in 1994, following Decree No. $61 / \mathrm{CP}$. The aims were to terminate the state housing monopoly, to encourage people's investment and engagement in housing renovation and maintenance, and, by the latter, to improve the physical condition of the existing housing stock. Money obtained from the sale of state owned housing was to be reinvested in the production of new housing (to be sold to the people), and in the renovation and upgrading of existing housing (People's Committee of Hanoi, 1999).

Privatisation of public housing in Hanoi was carried out in several stages. At first, it was applied experimentally to only a few buildings. From 1998, it began to be implemented on a larger scale, and applied to most state owned housing stock. The sale was slow during the first few years but increased notably after several subsidy policies were introduced. By the middle of 2004, more than 40 per cent of all state owned housing had been privatised. In the large housing areas, the percentage of owners is higher. More than 60 per cent of households are owner occupied in all but one studied area.

Both original tenants and those who bought the use-right are allowed to purchase the apartment, providing that they have the required papers. Original tenants need to have 
allocation papers or contracts. Those who have bought the use-right must be registered as 'permanent residents' and have legitimate papers.

Apartments are sold individually to tenants. The remaining apartments still belong to the municipal housing authorities. A situation of mixed ownership prevails in most housing areas, and in most blocks. In the owning certificate there is no specification about the rights and duties of the owners towards the blocks. In fact, there is no regulation about the rights and duties of owners, tenants or housing authorities towards the block. Works were still ongoing (by early 2004) to produce legal documents concerning tenants' and owners' rights and duties towards privatised residential blocks.

\section{Subvention Policy}

Privatisation of state owned apartments involves a high level of subsidy. First, land prices are set at only 10 per cent of the land use price for existing residents who buy apartments in the old housing areas. The prices of apartments are set at between 33-50 per cent of the construction cost, including depreciation. Apartments in upper floors cost less than those on the lower floors. In general, the apartments cost from 5 to 10 million VND depending on the year of construction and the building type. This is about one-third of the total, or half a year's income, of a state employee at the beginning of his/her career (approximately 18-24 million VND per year), and about 70 to 100 times lower than market prices ranging from 300 million to 1 billion $\mathrm{VND}^{2}$ (2004). This price applies to all tenants of state housing, both original tenants and those who bought use-rights, many of whom work in the private sector.

There are several other forms of subventions particularly directed to state employees. These can be in the form of discounts on the price of land use rights and/or the price of apartments. All government employees ${ }^{3}$ are entitled to a discount according to the number of years spent in state employment or military service. The standard discount is 100000 VND per year of employment per person (180 000 for those who work in the military or police). For a household with several family members working for the government, the discount for the household is the sum of the individual discounts, providing that this does not exceed the price of the apartment itself. State employees who have made many 'contributions to the revolution' get further discounts. ${ }^{4}$ Senior officials who joined the revolution before 1945 are exempt from payment. Furthermore, senior revolutionaries who live in apartment buildings are entitled to a subsidy of 20 million VND, in order to improve their living conditions (Decision No. 20/2000/QD-TTg). The land-use payment is exempt for those who have received medals for service during the war.

It is not difficult to come to the conclusion that this policy mainly benefits government officials and senior revolutionaries. Since many senior revolutionaries are more often than not officials in high-ranking positions, the policy can be said to support those who already have a better social and economic status. The question is whether it actually contributes to strengthening the existing inequality.

With no tax imposed on resale, and no requirements about the duration of stay after purchase, privatisation means a big financial gain for many owners, particularly for those who obtain a large discount or do not have to pay. Many earn a large profit by selling the apartments shortly after purchase. There is speculation that this might lead to a process of residualisation and segregation, where the better-off residents move to better housing and leave these old and degraded areas to poorer residents. 


\section{The Survey and Interviews}

The discussion in this paper is mainly based on the findings from a survey carried out in May and June 2002, and some early findings from the in-depth interviews carried out in November and December 2003.

\section{Selected Housing Areas and the Survey}

Six different housing areas, that were the most representative of housing areas in Hanoi, were selected. Three of these areas are centrally located (Nguyen Cong Tru, Giang Vo and Trung Tu), two are $5 \mathrm{~km}$ from the centre (Quynh Mai, Nghia Tan) and one is located $10 \mathrm{~km}$ away (Thanh Xuan Bac). Three of these were considered to be successful examples of apartment buildings (Trung Tu, Giang Vo, Thanh Xuan Bac).

Nguyen Cong Tru and Quynh Mai (Figures 4 and 5) are two of the oldest areas in the city. Nguyen Cong Tru was built from 1961 to 1963. Quynh Mai has blocks from both the 1960s and 1970s. These are smaller housing areas of 6 to 8 ha and they have 14 and 17 blocks respectively. The blocks are I-form, situated parallel to one another. Services such as department stores and kindergartens were built later in these areas.

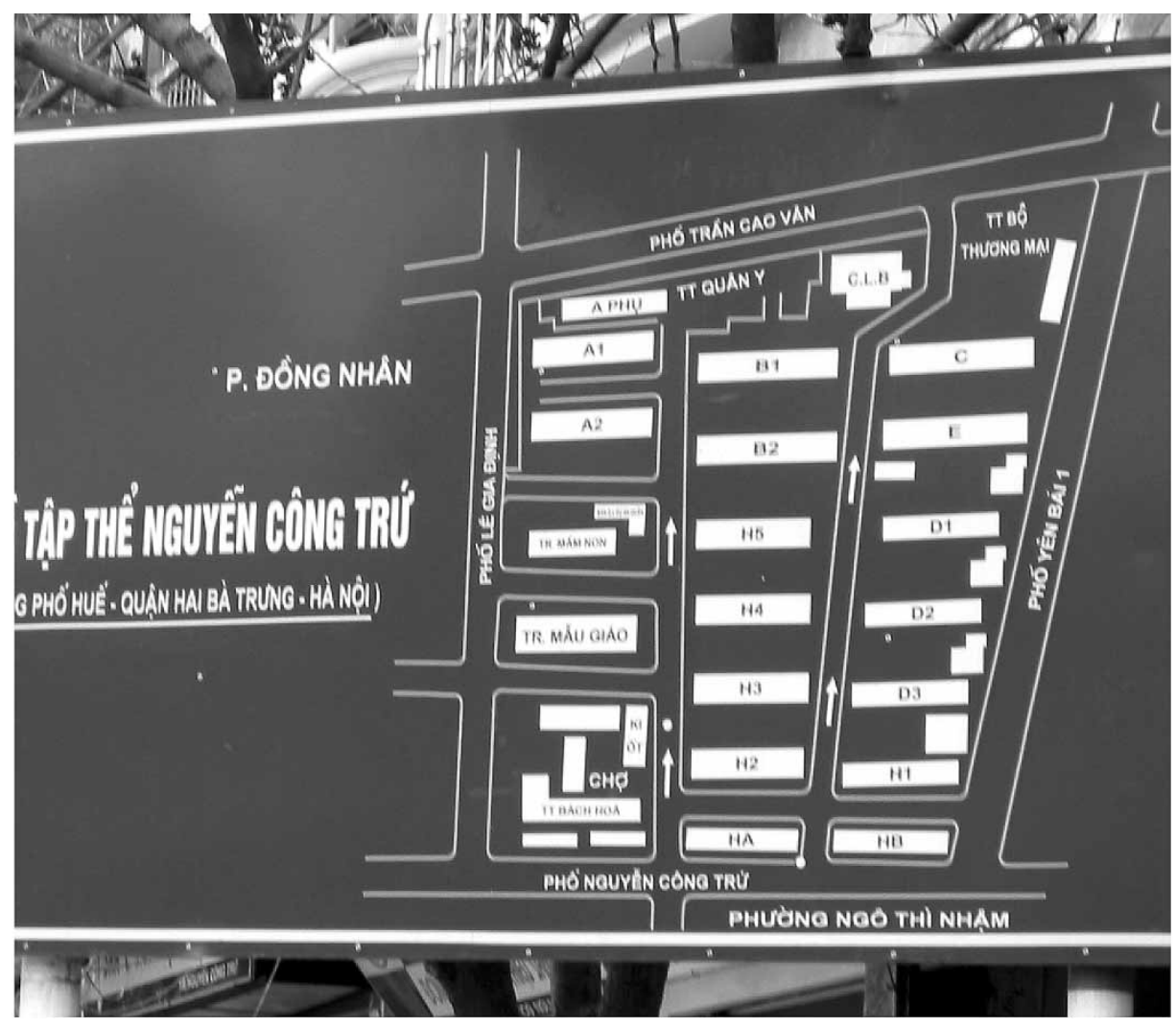

Figure 4. Nguyen Cong Tru area and Quynh Mai area 


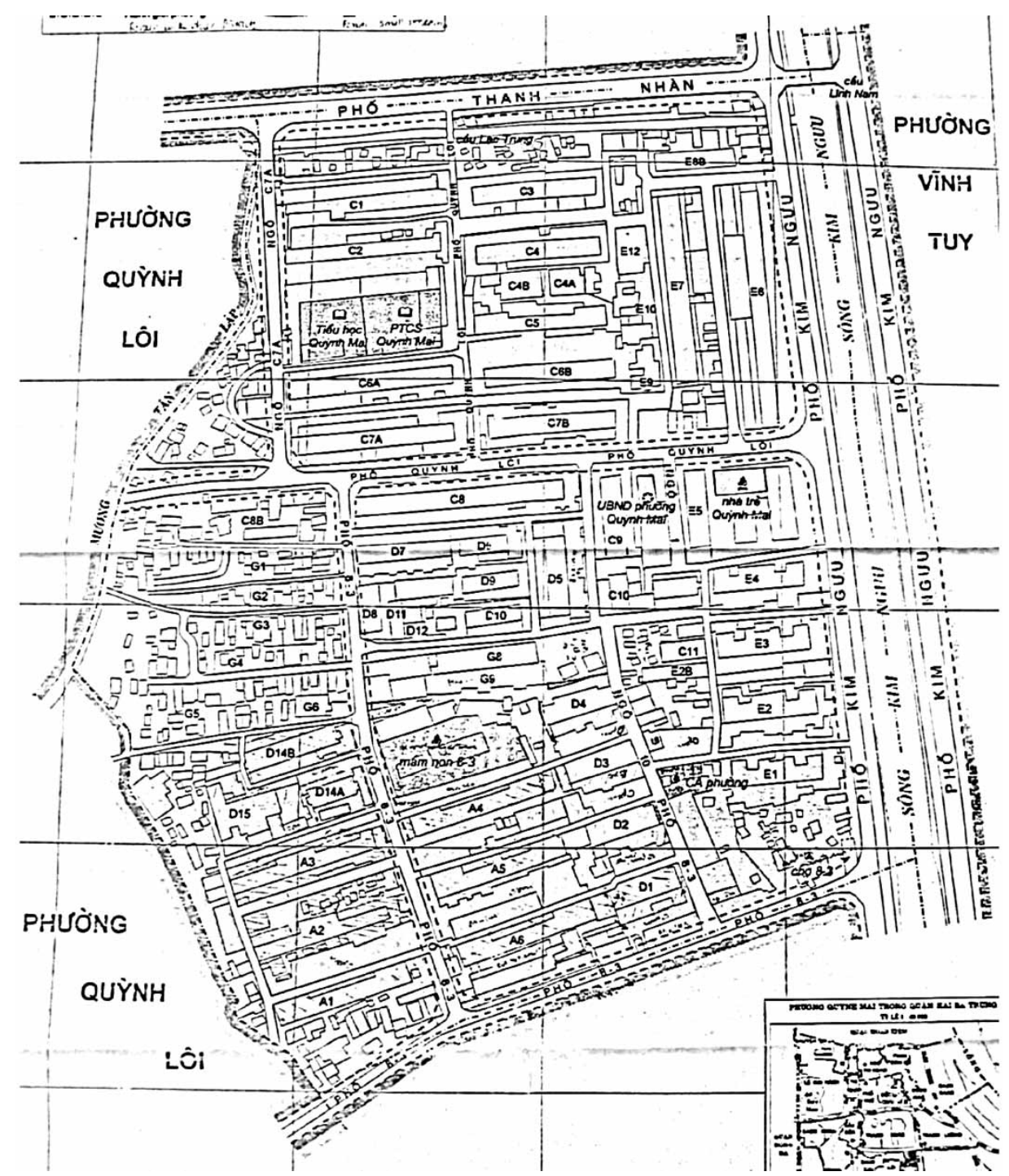

Figure 5. Nguyen Cong Tru area and Quynh Mai area

There are few layout variations depending on when the blocks were built. In older blocks, built during the 1960s in both areas, the apartments do not have their own kitchen or toilet. In the Nguyen Cong Tru blocks, there are four to five one-roomed apartments of 22 to $25 \mathrm{~m}^{2}$ at each side of the staircase, sharing one common kitchen and toilet. In the older blocks of Quynh Mai, there are eight to 10 identical apartments $\left(18 \mathrm{~m}^{2}\right)$ on each floor sharing one common kitchen and toilet. In the later blocks built in the 1970s, the apartments are 24 to $28 \mathrm{~m}^{2}$, having two rooms, their own kitchenettes and toilets.

The remaining four areas, Giang Vo, Trung Tu, Nghia Tan and Thanh Xuan Bac, are much larger and were built from the mid-1970s to mid-1980s. Each area was designed to 
be self-contained, with a central elementary and secondary school, surrounded by groups of apartment buildings (Figures 6, 7,8 and 9). There is a day-care centre in each group. Most of the blocks were built from prefabricated concrete panels and apartment roofs. Giang Vo and Trung Tu still have the I-form blocks situated parallel to one another, with apartments lined along a side corridor. The apartments here are of 24 to $28 \mathrm{~m}^{2}$ with their own kitchen and toilet. Thanh Xuan Bac has more variations, both in block forms and in apartment layouts and sizes $\left(16,24,34\right.$ and $\left.41 \mathrm{~m}^{2}\right)$.

In most of the blocks included in this survey, mixed ownership prevails. Owners form the majority group in most buildings, with the exception of one building in which the number of tenants doubles that of owners and one building which is wholly occupied by owners.

The survey method was face-to-face interviews using a structured questionnaire. The questionnaires were developed and tested in test interviews by the Swedish researchers

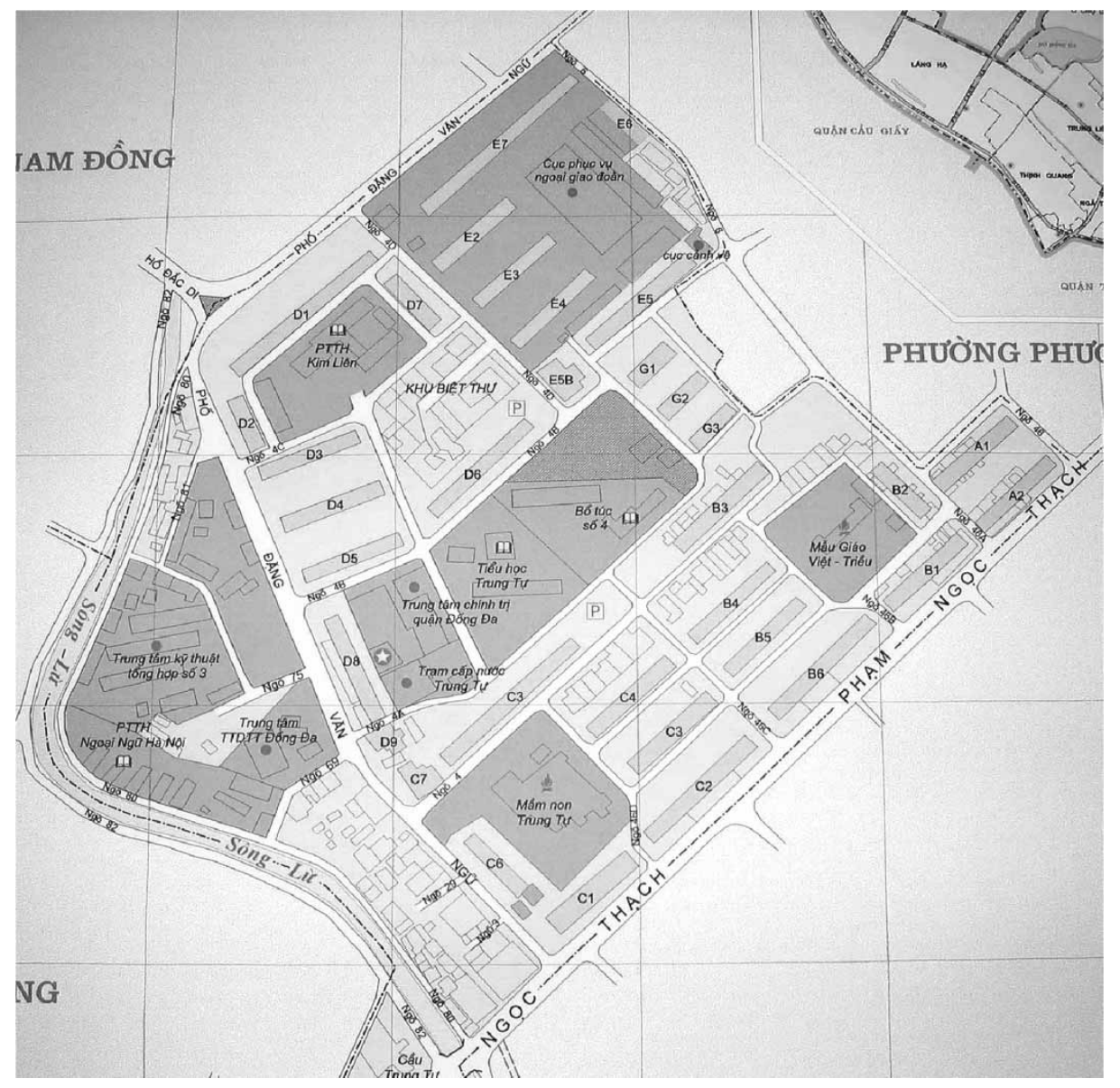

Figure 6. Trung Tu area and Nghia Tan area 


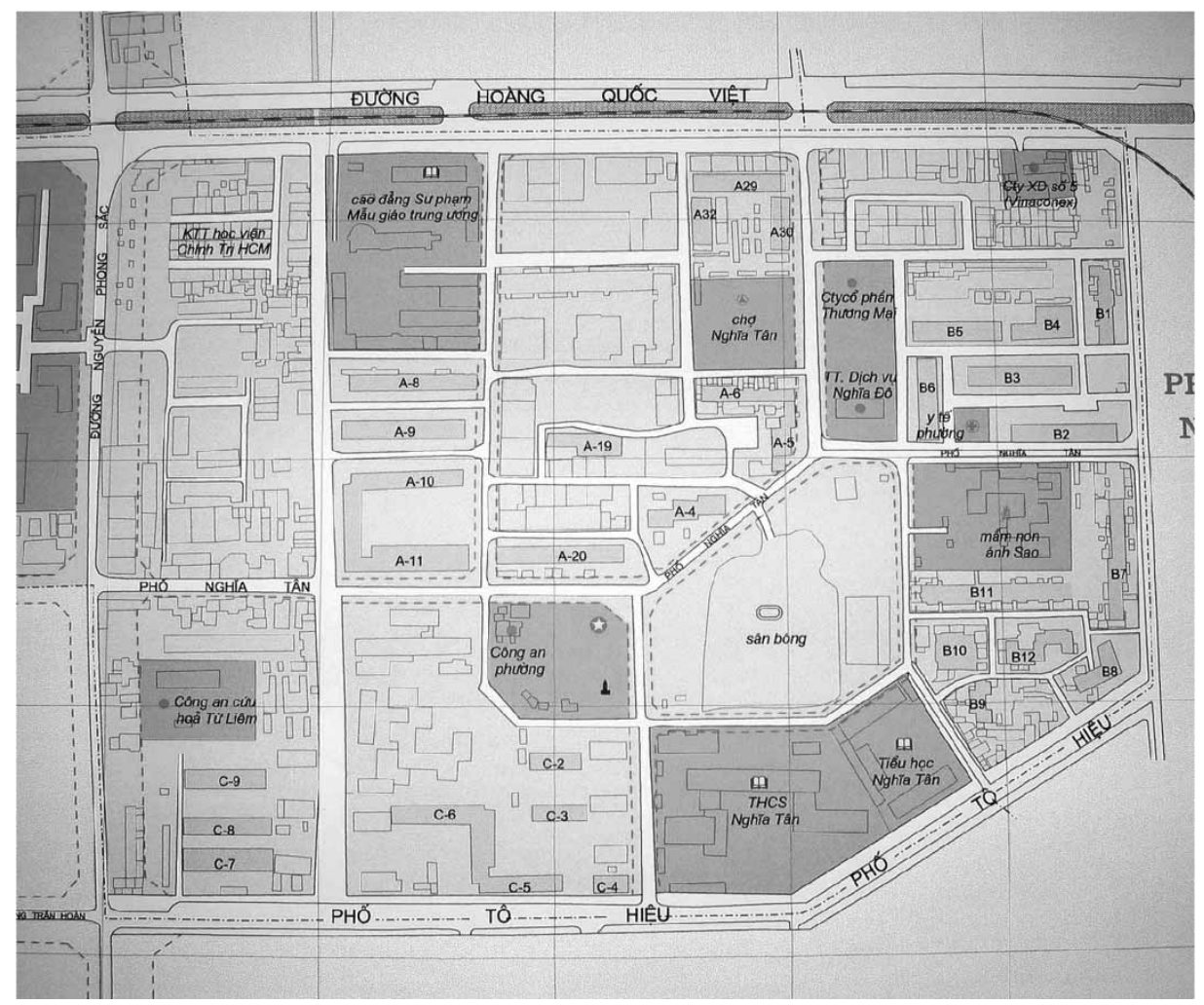

Figure 7. Trung Tu area and Nghia Tan area

together with the Vietnamese researchers from the Institute of Sociology in Hanoi, who later carried out the survey.

Eighteen buildings were investigated. These were older buildings that used traditional building techniques, as well as later buildings made from prefabricated concrete panels. Early layouts, without kitchen and toilet, and later layouts with independent utilities were included.

A total of 120 tenants and 120 owners (20 owners and 20 tenants from each of the six housing areas) were interviewed face-to-face using a detailed questionnaire. Different types of households, such as households that included retired people, people mid-way through their careers, young people and people working in the private sector, were included in the samples.

Since it was difficult to access the households in some of the blocks, the number of households interviewed in each block was not the same in all the blocks in a housing area. The results are thus comparable in terms of areas, but not in terms of blocks. On the other hand, in terms of the interviews that were carried out, the response rate was very high: a 100 per cent response to all the basic questions and more than 90 per cent to more sensitive or difficult questions such as income, management issues, etc.

The materials obtained were registered and analysed using the SPSS program. This paper only presents a small part of the material. 


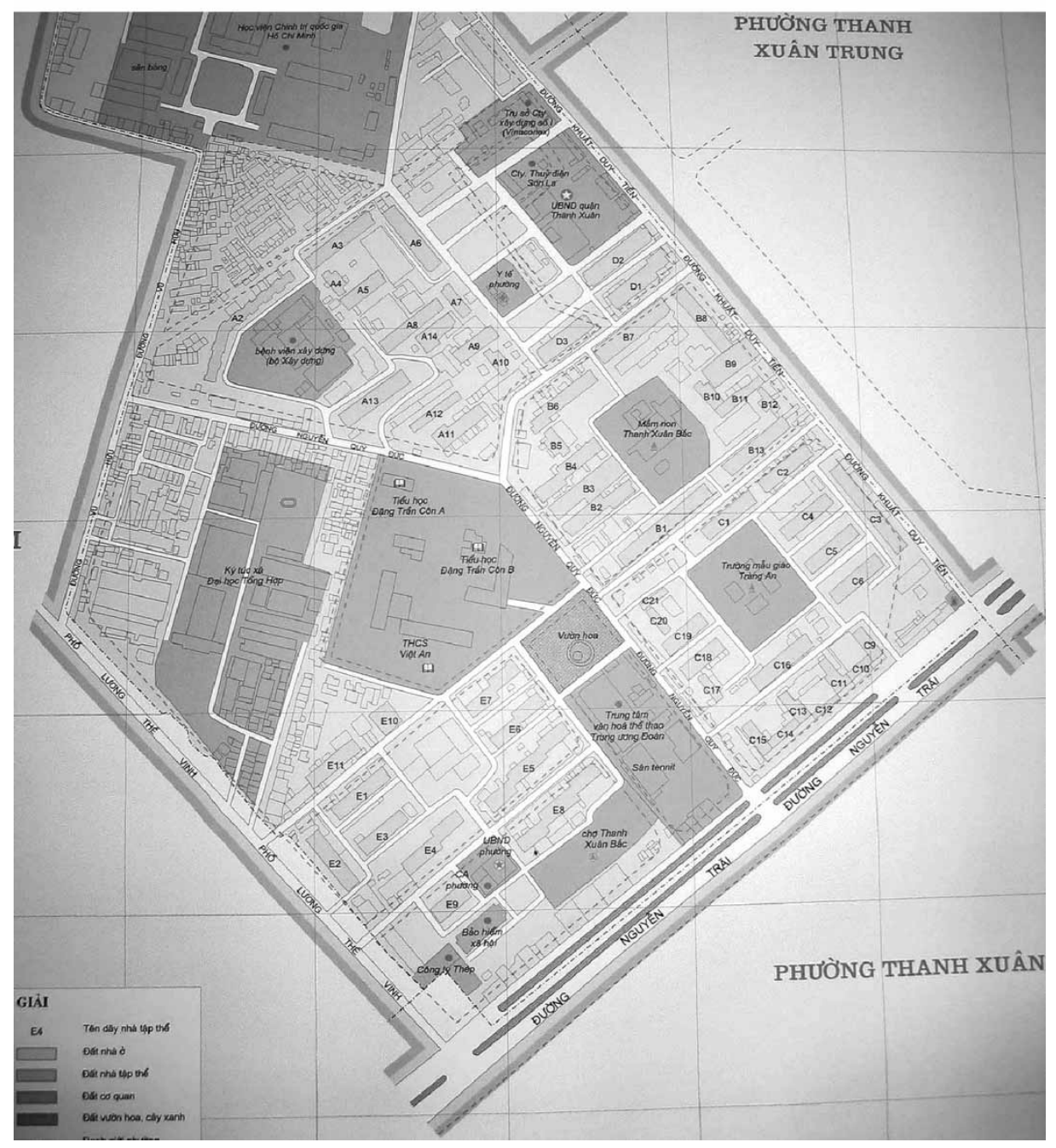

Figure 8. Thanh Xuan Bac area and Giang Vo area

\section{The In-depth Interviews}

Complementary to the survey, in-depth interviews were carried out with 40 households (both owners and tenants) in two of the selected housing areas. One area has relatively good conditions and better social status (Trung Tu); the other is much more degraded and of lower social status (Quynh Mai). Trung Tu has the highest percentage of owners (80 per cent of residents) while Quynh Mai has the least owners (45 per cent of residents) among the six investigated areas. Two blocks in each of these areas were selected for the in-depth interviews. Ten interviews were conducted in each block.

In these interviews, the focus was on the residents' view of being an owner or tenant, how they became owners, the meaning of ownership, the ownership status of the block and their opinions about the care of the building after privatisation. The interviews also tried 


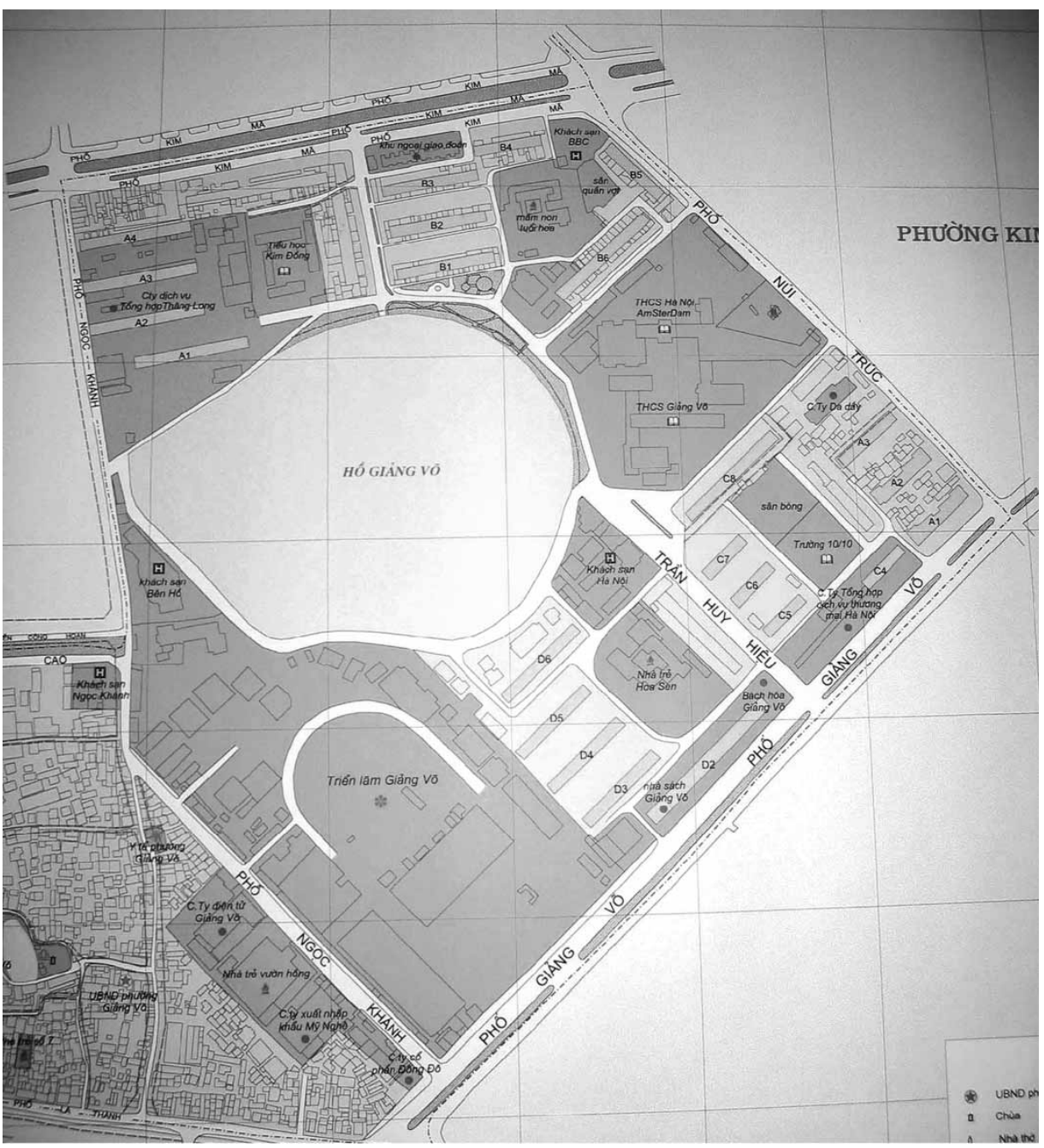

Figure 9. Thanh Xuan Bac area and Giang Vo area

to find out about the residents' satisfaction or dissatisfaction with their current housing situation, their opinions about the apartments and the housing area, their housing plans and wishes.

The interviews were structured but open. A list of pre-drafted questions was used as a checklist, but the interviewees were given the space to tell their stories in their own way. The interviews took from one to two hours. All interviews except one were taped. Drawings of the layouts were made, and the furnishings and use of space was noted.

The paper presents the findings from the interviews that complement and clarify findings from the survey. They include a general profile of the residents, their housing histories, living standards and future housing plans, as well as their views on homeownership. Differences between tenants and owners are highlighted and the link to privatisation policies discussed. The stories of two households are used as an illustration of some of the 
themes. These are followed by a discussion about the impact of privatisation on social equality/inequality, housing quality and other issues that are raised by the findings.

\section{Residents' Profiles: Owners Versus Tenants}

This profile focuses on the similarities and differences between tenants and owners. The head of the household (usually the one to whom the apartment was allocated and whose name is on the contract) was chosen to represent the household. As such, findings about employment, age, education, gender, income, or work place, for example, refer to the head.

\section{Senior Owners But Younger Tenants}

The findings show that owner households are more senior and tenant households are younger. The majority of owners are retired people (55.8 per cent.) Forty per cent of tenants and only 15.0 per cent of owners are less than 40 years old (Figure 10).

That a large group of owners are retired is a direct consequence of the sale policy. The majority of these have been senior state employees who are entitled to a considerable discount based on their years of employment and contributions made during the war; thus they can buy apartments at a very favourable price or at no cost at all. It can be said that this group is supported by the state to become owners.

The in-depth interviews indicate that, among those who were supported to become owners, it is mainly retired people with meagre salaries who stay in the area. Those who have work and a relatively good income were not slow to sell the apartment and buy a better dwelling elsewhere.

In the tenant group, there is also a large group of households that are state employees (46.7 per cent), and a considerable group of retired state employees. The interviews indicate that many of the state employees in this group are newcomers in the area, and therefore not yet registered and lacking the appropriate papers required for purchase. In poorer housing areas there are also households that include senior state employees and where the sale has not been implemented, or implemented for only a short time, and therefore the household did not have the chance to buy. State employees in better housing areas have thus a better chance to become owners. In poorer housing areas, there are more state employees among the remaining tenants.

Among those who are from the private sector but who have remained tenants, many engage in small family businesses (noodle restaurants or tea shops) or in services (such as barbers or motorbike guards) and they have low incomes. While people who work in the private sector and who have better incomes will gladly pay the set price in order to own their own apartment, lower-income households find the purchase beyond their reach.

Several young tenant households are students who have come from other provinces to study in Hanoi. Many are new and do not yet have registration. It is common that two or three of these students (usually brothers, sisters or relatives) share an apartment. Several rent second-hand, of an overall 14.2 per cent of tenants who rent second-hand.

\section{Owners Had State Housing Allocation; More Tenants Bought Use-Rights}

The majority of owners obtained their apartments from their work places and 17.2 per cent obtained their apartments by buying the use-right (before privatisation). This group is 


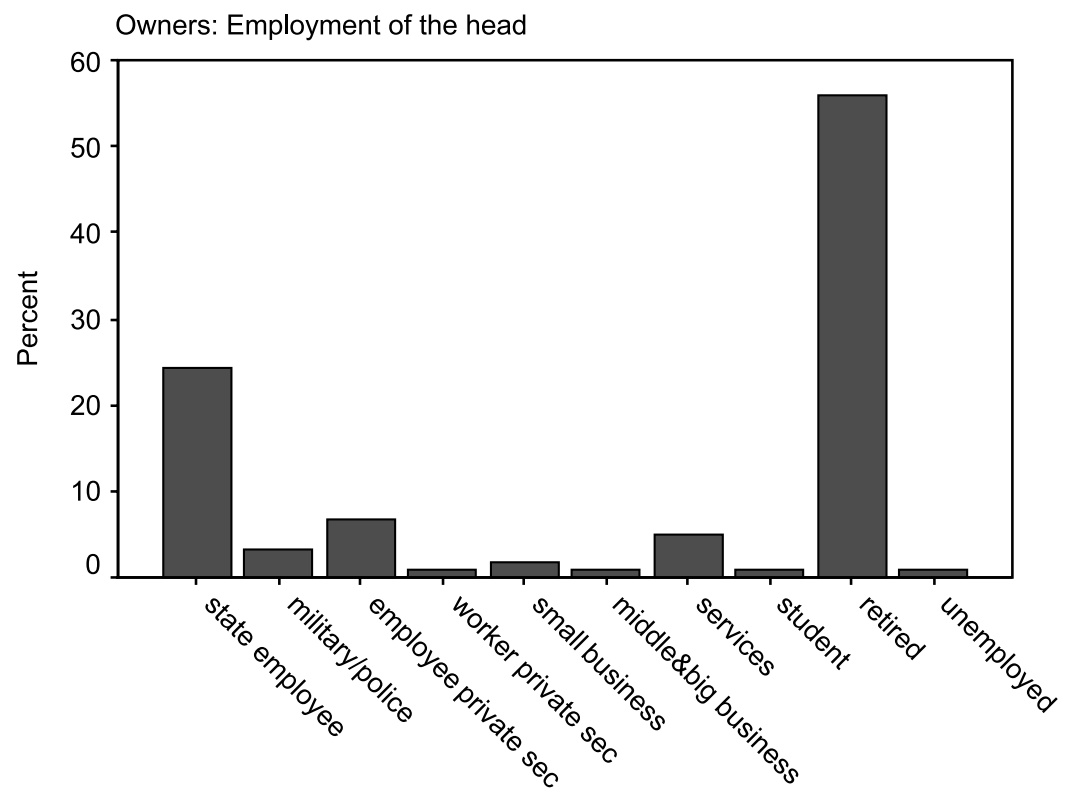

Owner household Employment of the head

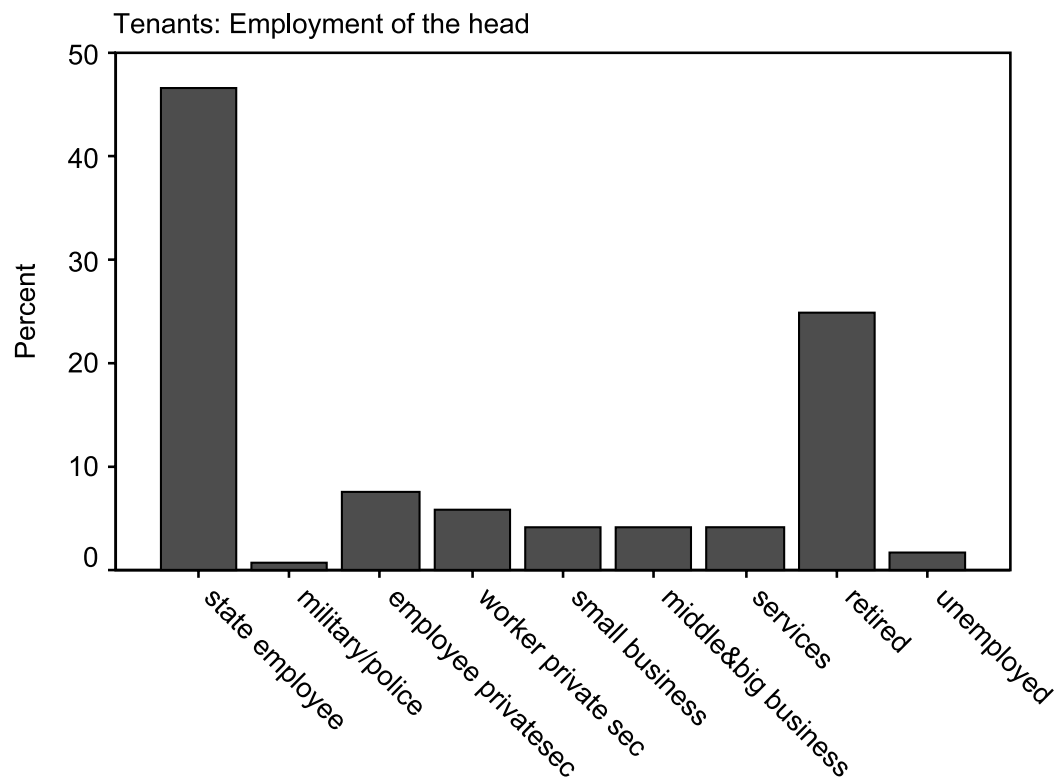

Employment of the head

Figure 10. Owners are older, tenants are younger 
much larger among tenant households: 40.0 per cent bought use-rights (Figure 11). Among these, a large group are state employees (47.9 per cent in employment, 14.6 per cent retired), most likely belonging to weaker work places that could not provide them with housing. A significant group, 35.4 per cent, works in the private sector.

Among the few owners who bought the use-rights (17.2 per cent), only a small group works in the private sector (19.1 per cent). In general, there are more people working in the private sector in the tenant groups, especially among those who bought the use-rights.

If the number of residents who were allocated housing from their work place is considered to represent those who are favoured by the housing policy prior to privatisation, and those who bought the use-right to represent those who are 'less favoured', it can be said that there are more of those who are supported in the owner group and more of those 'less favoured' in the tenant group. In other words, it is the (already) 'favoured' who become owners.

\section{Male Owners But Female Tenants}

There are more male-headed households (55.8 per cent) than female ones ( 44.0 per cent) in the owner group. In contrast, in the tenant group, the number of female-headed households (51.7 per cent) is somewhat higher than the male-headed ones (48.3 per cent).

Does the sale policy play a role here? It probably does. Allocation of housing on the basis of employment allows both men and women to be household heads and this explains the large number of female-headed households. However, since the sale policy favours people who have made 'contributions to the revolution', and since many of those in high-ranking positions are men, the consequence is that more male than female household heads become owners. State employees who remain tenants are those who are less, or not at all, favoured by the sale policy, and as can be seen, many of these are female-headed households.

\section{Owner Households Are Larger and Have More Income-Earners}

The majority of households in both groups are made up of three to four people. There are slightly more tenant households among households of two to four people. Among larger households (five or six) there are more owner households.

The majority of owner households and almost half of the tenant households have two main income-earners. There is a significant group of owner and tenant households that have three or four income-earners, and there are more owner households than tenant households in this group (Figure 12).

That owner households are somewhat larger and have a higher income seems also to be a consequence of sale policies that favour senior state employees. Since the discount of the apartment is the sum of the discounts of all individual members, a household that has several state employees gets a larger discount, and thus is likely to get the apartment for free. The interviews show that retired state employees with several grown-up children who work in the state sector are favoured by this policy.

\section{Owners Have Been Living Longer in These Areas; Tenants Are Newcomers}

There are more owners than tenants among those who have been living in these housing areas for a longer time. In total 42.5 per cent of owners came here between 1976 and 1987 , 


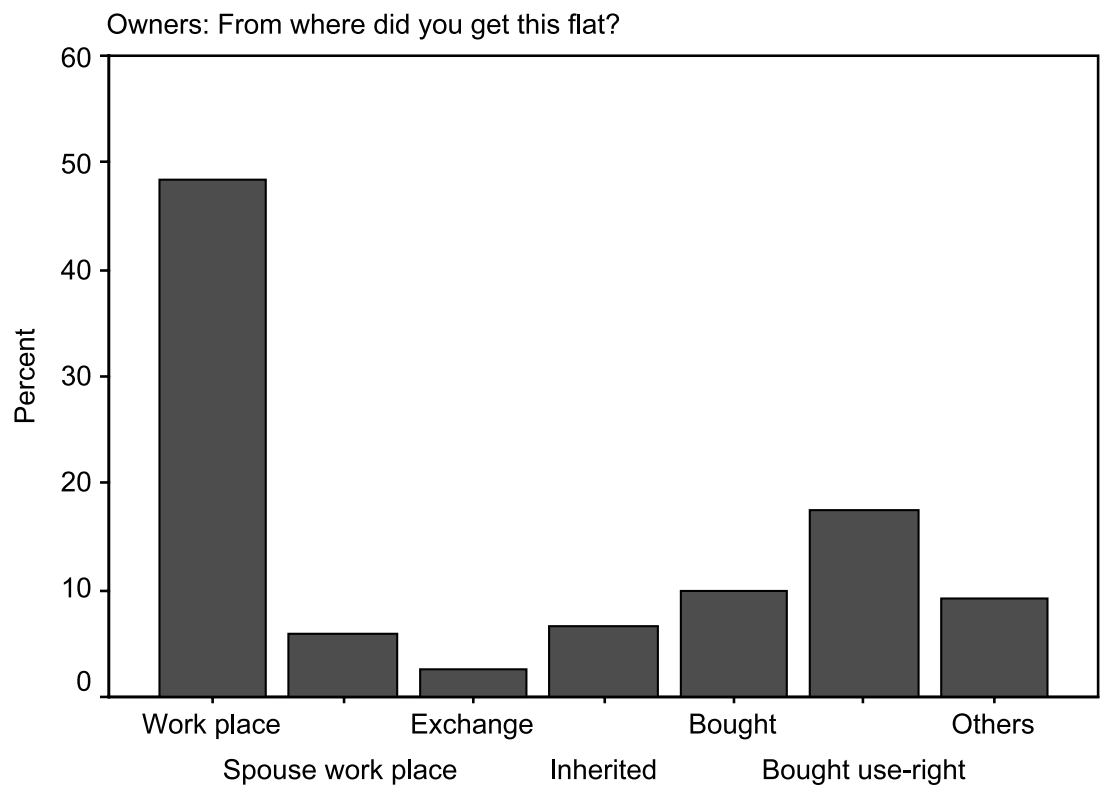

From where did you get this flat?

Tenants: From where did you get this flat?

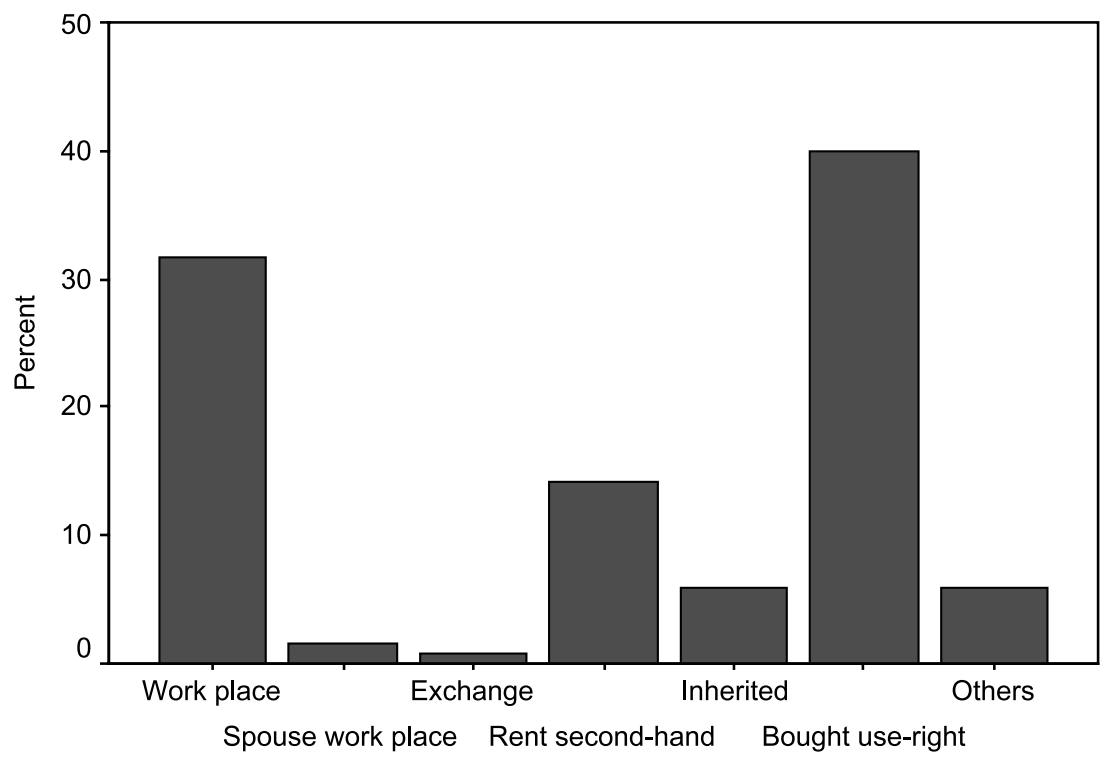

From where did you get this flat?

Figure 11. Owners receive state housing allocation, tenants bought use-right 
Owners: Number of income earner

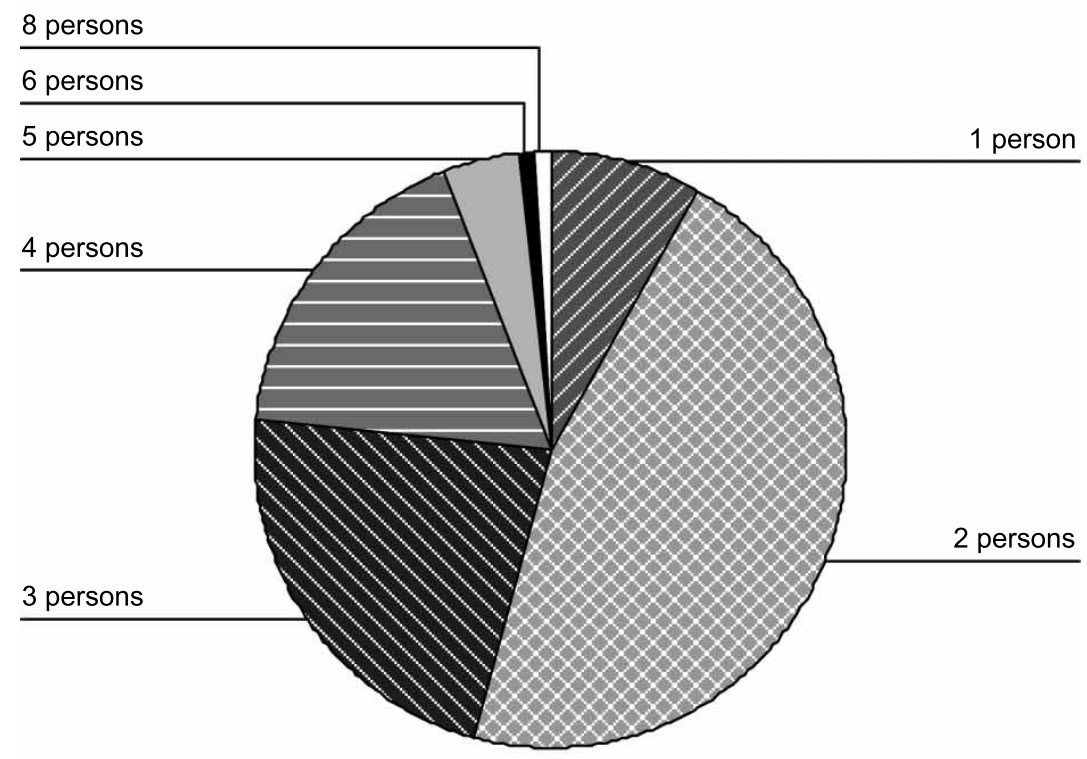

Tenants: Number of income earner

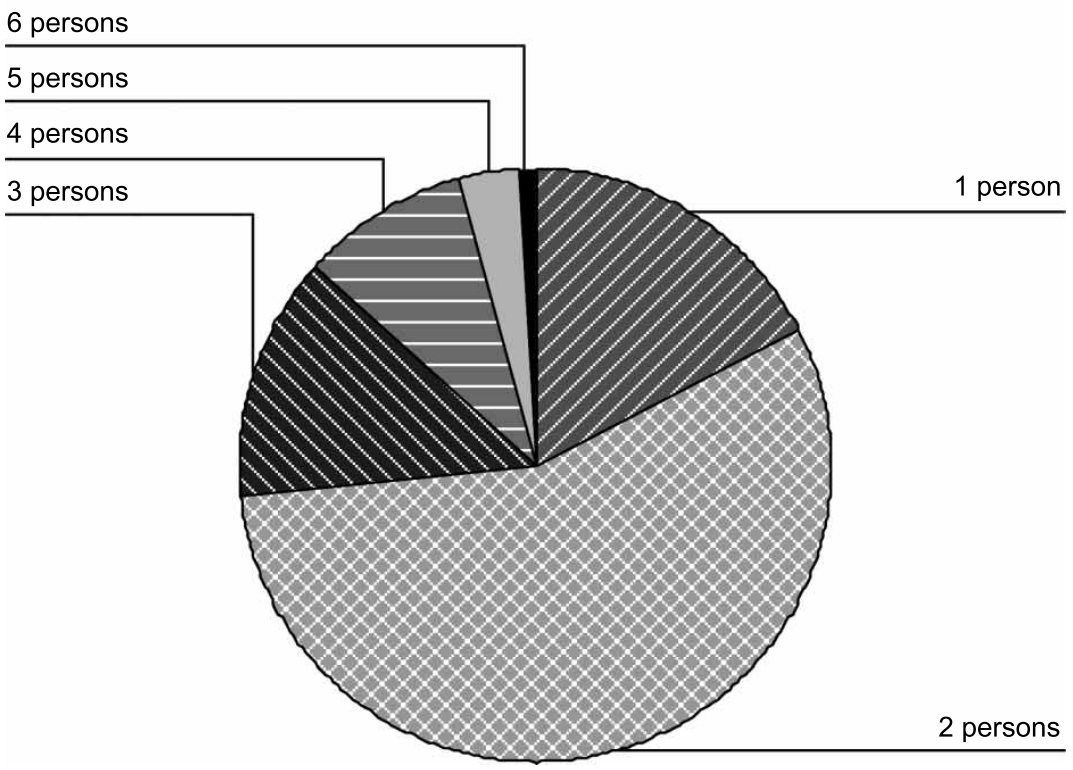

Figure 12. Owner households have more income-earners 
while only 7.3 per cent of tenants came during the same period. Many tenants are newcomers: 30.9 per cent came between 1992 and 1998, and 23.3 per cent have only been there since 1999 (Figure 13). This is another consequence of the sale policy. Senior state employees, who got state housing location early from their work places, are also those who are qualified for most subventions and become owners without having to pay. In addition, the policy that requires permanent resident status to be allowed to purchase apartments, a measure used to prevent immigration to the city, contributes to putting new tenants in a less favourable situation with regard to access to housing and ownership.

The findings also indicate some differences in residential mobility between different housing areas, especially in the tenant group. Better-off areas are more stable, with lower mobility rates. Poorer areas seem to have become a temporal housing platform with a high level of mobility. In Quynh Mai, more than 50.0 per cent of tenants are newcomers who had come to the area since 1997. In Trung Tu, only 15.0 per cent of tenants are newcomers (those who have lived in the area less than five years).

\section{Owners Have More Living Space}

The survey shows that owner households have larger living spaces compared to tenants. The majority of owner households have a total living space of between $40-80 \mathrm{~m}^{2}$ whereas the majority of tenant households have $20-40 \mathrm{~m}^{2}$. No owner household has less than $20 \mathrm{~m}^{2}$ total living space, but up to 7.5 per cent of tenant households have this small living space.

In terms of living space per person, owners are also better off than tenants. While the majority of tenants and owners have an average living area per person of $10-20 \mathrm{~m}^{2}$, there are more owners who have a living space larger than $20 \mathrm{~m}^{2}$ (Figure 14). Although owners have a higher percentage of the largest living space per person, there are quite high percentages of tenants who have the largest living space. However, there are more tenants who have less than $6 \mathrm{~m}^{2}$ per person. This indicates a wider gap among tenants and a higher level of homogeneity among owners.

The in-depth interviews indicate a clear inequity in living space among residents in connection to their work units. Senior employees belonging to poorer work units get smaller apartments in poor housing areas while those belonging to more powerful work units have larger apartments in housing areas of higher status. There are several cases of state employees belonging to the poorer work units (such as elementary schools) who had to buy use-rights.

\section{Owners Have Higher Living Standards}

The findings indicate that owner households have a higher living standard than tenant households. Owners have more expensive appliances and furniture compared to tenants, for example, air-conditioners and lounge suites (Table 1).

Owner households have better kitchens, equipped with gas stoves and kitchen cupboards. Their bathrooms are better equipped, with showers, water boilers, washbasins and washing machines. The majority of owner households ( 71.7 per cent) have upgraded their toilet and installed a WC, while only less than half of tenant households (48.3 per cent) have a WC. There are many more tenant households than owner households who have to share a bathroom and toilet with other households. 
Owners: When did you come to live here

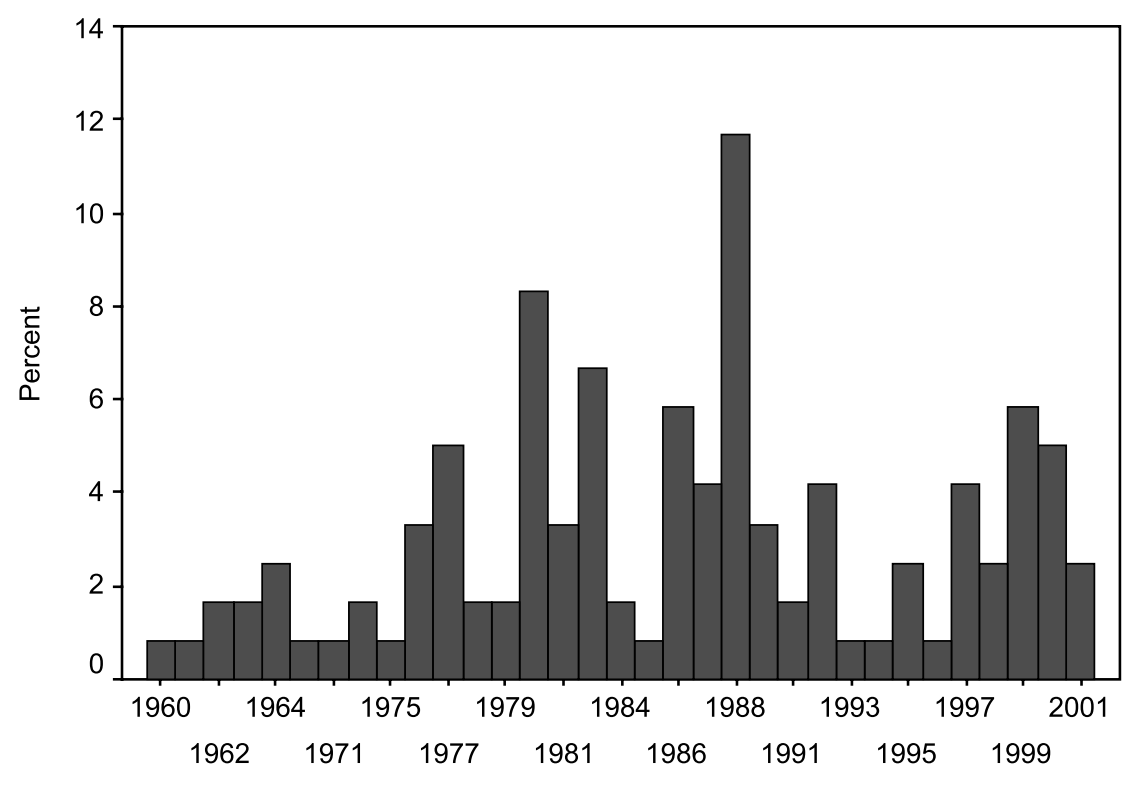

When did you come to live here?

Tenants: When did you come to live here?

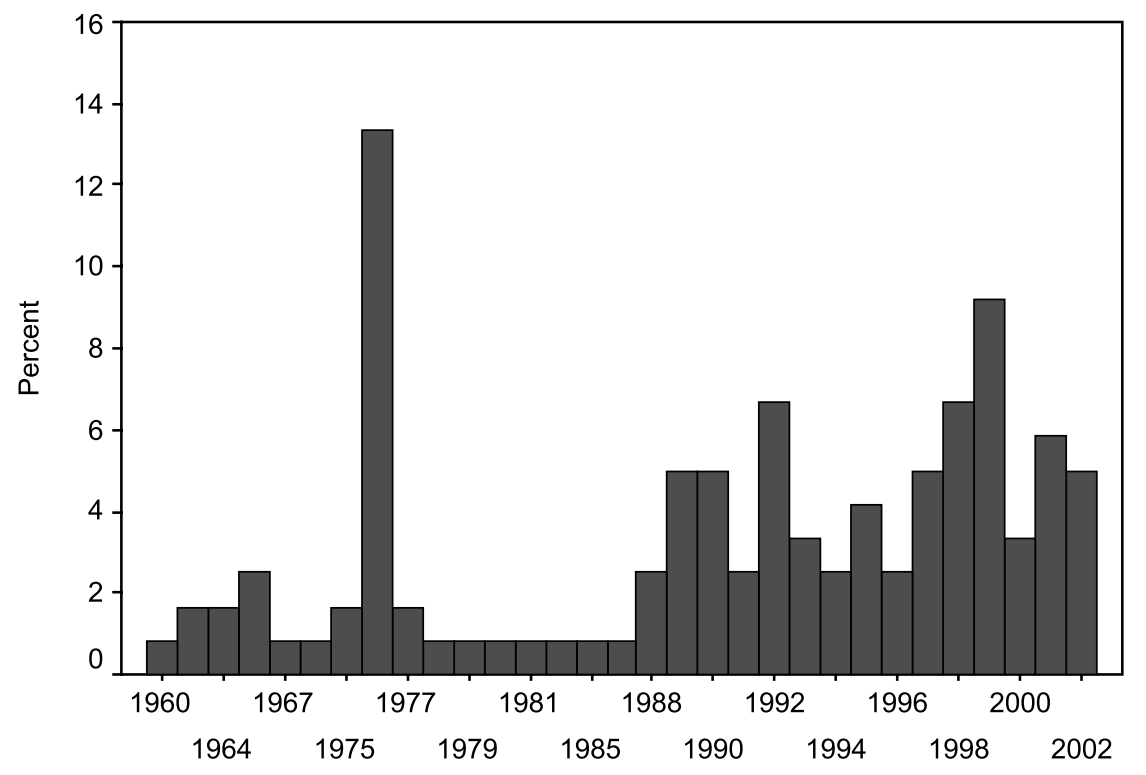

When did you come to live here?

Figure 13. Owners have been living longer in the area 
Owners: Total living space

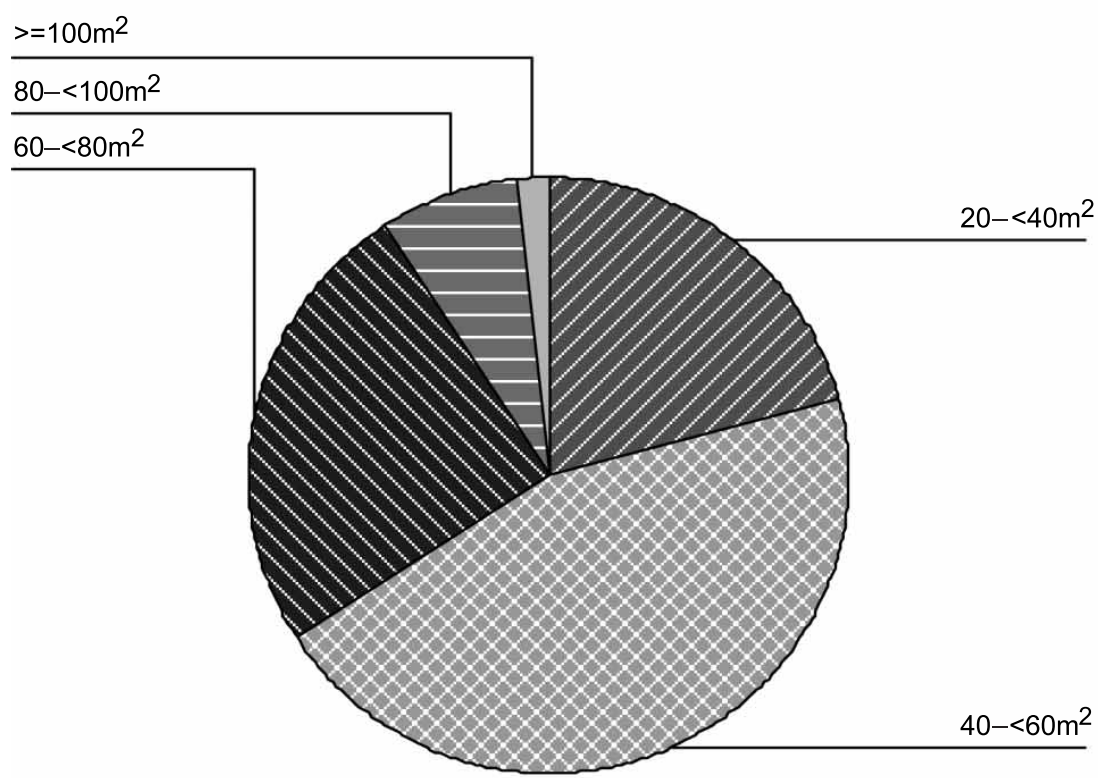

Tenants: Total living space

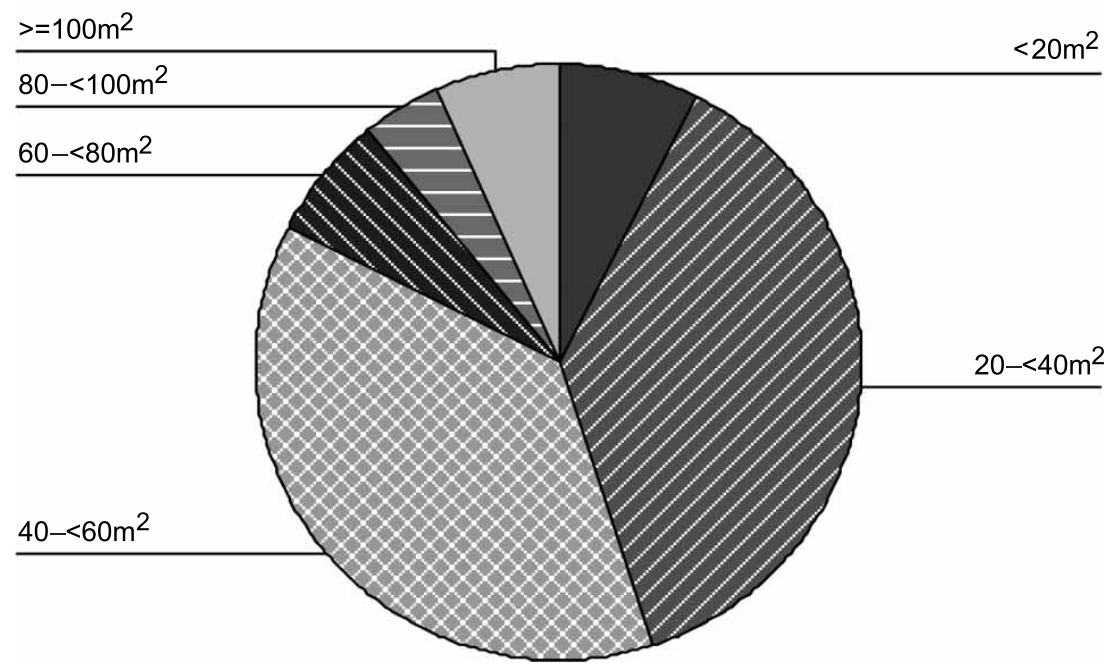

Figure 14. Total living space of owner households compared to that of tenant households 
Table 1. The living standards of owners and tenants

\begin{tabular}{lcc}
\hline Expensive home appliances and equipment & Owner households $\%$ & Tenant households \% \\
\hline Air conditioner & 15.0 & 05.0 \\
Sofa & 80.0 & 64.2 \\
Video, DVD players & 72.5 & 68.3 \\
Stereo players & 36.7 & 29.2 \\
Vacuum cleaner $^{\mathrm{a}}$ & 05.0 & 03.3 \\
Gas stove & 85.8 & 75.8 \\
Kitchen cupboard & 43.3 & 27.5 \\
Shower & 72.5 & 52.5 \\
Washing bowl (in the bathroom) & 61.7 & 50.0 \\
Water boiler (bathroom) & 61.7 & 43.3 \\
Washing machine & 48.3 & 30.0 \\
WC & 72.5 & 48.3 \\
Shared bathroom & 01.7 & 10.8 \\
Shared toilet & 02.5 & 15.0 \\
\hline
\end{tabular}

${ }^{\mathrm{a}}$ The local climate in Hanoi, with very high humidity, probably contributes to the low popularity of vacuum cleaners among the households.

The survey also shows a larger gap in living standards within the tenant group, and a higher level of homogeneity in living standards within the owner group. There is also a clear gap in living standards among tenants from different living areas. Better-off housing areas, such as Trung Tu, have more better-off tenants. There are more poor tenants in poor areas, such as Quynh Mai. On the other hand, there is no clear difference in living standards between owners in different housing areas.

\section{Inequality Between Housing Areas}

It was mentioned earlier that, in the old days, work places were responsible for providing housing to their employees. Better and more powerful work places have more and better quality housing to provide to their employees, while poorer work places have little or no housing at all. As such, there already existed a certain inequality between the housing areas depending on the position of the work places. This was expressed in the number of residents who obtained their apartments from their work place versus those who bought the use-right. With the subvention policy supporting senior officials of ranks to become owners, privatisation can be seen to contribute to the further increase of inequality among the areas, expressed in the percentage of owner households as compared to that of tenant households.

More Original Residents in Better-off Areas; More of Those Who Bought the Use-right in Poorer Areas

The findings show a clear difference between the housing areas in the number of original tenants and those who bought the use-right. The more attractive areas (better physical conditions or attractively located) have a higher percentage of residents who obtained their apartments from their work places, and a lower percentage of residents who bought the use-right. In the poorer areas, there is a high percentage of those who were not allocated housing. With those who were allocated housing from their work place representing those 
who were favoured before privatisation, and those who bought the use-right representing those who are not, it can be said that the better-off housing areas have more 'favoured' residents and the poorer housing areas have more residents who are not favoured.

\section{More Owners in Better-off Areas}

The investigation also shows that better-off housing areas have a higher percentage of owners $(60-80$ per cent), compared to poorer housing areas (30-45 per cent). There are more tenants in poorer housing areas.

In this study, Quynh Mai is a housing area with very poor conditions and the blocks studied in this area belong to a textile factory that has not been very productive for many years. The blocks studied are very much dilapidated. At the other end of the spectrum is the Trung Tu housing area, which is in a notably better condition. The blocks studied are in relatively good condition. They belong to the Ministry of Police, a powerful work place both in terms of status and financial capacity. Trung $T u$ has more than 80 per cent owner residents, almost twice as much as Quynh Mai (45 per cent).

In the blocks investigated at Trung Tu, there are many middle to high rank government officials who are entitled to many discounts and do not have to pay for their apartments. It is thus not surprising to find a high percentage of owners here. The few remaining tenants are those who do not have enough papers or who do not fulfil the requirements to buy, such as in the case of people who recently moved to the apartments from another province. ${ }^{5}$

The reverse situation occurred in the Quynh Mai blocks. Here, the majority of the residents are textile workers or low rank employees of the textile factory. Sale of housing stock was implemented for only two years then stopped in order to wait for a redevelopment plan. Many residents were thus not given the chance to become owners.

\section{Owners Receive Double Subvention and Tenants Are Excluded}

The survey shows that the majority of owners received large discounts to purchase their apartments. One-third did not have to pay (33.3 per cent). The majority of tenants wanted to buy, but they could not do so because they did not have enough money (42.5 per cent) or lacked the required papers (14.2 per cent). A high percentage of all tenants intend to buy their apartments at a later date (78.3 per cent).

The interviews show that the subvention policy is the deciding factor in the tenure outcome of the residents. There was not much choice involved in the tenure decision of the majority of owners. Several owners said: "Buying? We only did the required formalities to get the certificate". Others said: "We only follow the decree of the government". Many owners, especially higher-level officials, see this as a fair payback for their long and loyal service. Some call this a 'gift'. Not many reflect on the transformation in tenure in terms of duties and rights.

The interviews confirm that it is senior state employees who obtain the most subsidies. Young families and people in the private sector are not supported. Among those who were not supported there were several poor households with one income-earner.

A hierarchy of benefits can be observed, depending on the rank and work place of the residents.

At the top position, there are high and middle-ranking government officials (including retired officials), who have previously enjoyed the most favourable terms for housing 
allocation, and now receive the most subventions. First, they were provided with state housing. Then they were supported to become owners at very low cost or no payment. Senior revolutionaries received further housing support in cash. Resale of the apartments at market price provides owners with further benefits. Since there is a big price difference between new apartments and old apartments only the very well-off can sell and buy new apartments or houses. It is these people who gain most from privatisation.

Employees of lower rank or belonging to weak work places did not get housing allocation and had to buy use-rights, which implied a financial burden. Many of these live in housing areas with poorer conditions, where the sale was not initiated or was stopped, so they could not buy and they were therefore excluded from privatisation subvention.

People with a good income in the private sector also benefited. Although not entitled to discounts, they enjoyed the subsidised low price set up for residents in these areas, and were not slow to buy.

At the bottom of the hierarchy are young households in the state sector, and poor and low-income households in the private sector. They suffer several neglects. First, they did not get a housing allocation, and had to purchase the use-right. Second, they received no discount to buy their apartments and thus could not buy. Poor households with one income-earner have the poorest housing conditions.

Below are the stories of two households: one is a household of two senior officials with two apartments and good economic conditions, living in a renovated block. The other is the household of a former worker with three grown-up children living in an apartment without a kitchen or toilet in an old housing area.

\section{A Household of Two Senior Officials}

There are three generations in this household. Mr L., 76 years, retired from his post as head of a department at the Ministry of Police. His wife is 75 years old, also retired from the same work place. The son, 48 years old, works at the same ministry. His wife, 42 years old, works at a confection company. The boy, 18 years old, is studying.

The apartment belongs to the old couple, who obtained it from their previous work place, the Ministry of Police. The family came to live in this block in 1978 when Mr L. was promoted to the position of head of department and was given two apartments.

The block they live in has been renovated by the city by adding a building body to the short side of the original building in order to increase living space. The original apartment is $28 \mathrm{~m}^{2}$, the annex is $30 \mathrm{~m}^{2}$. The old couple lives in the original apartment; the son's family in the annexed space.

In 1998, directly after the sale was implemented in this area, they 'bought' the two apartments according to the privatisation policy. Since Mr L. and his wife have many years of employment at the Ministry of Police, they did not have to pay. They have several medals from the war and did not have to pay the land price. As a senior revolutionary, his wife got a further 20 million VND in housing support. Soon after they got the certificate for the apartments, they sold one apartment to buy a house in another district for the elder son.

For this couple, to buy involves no decision. They did not even mention the word buying. They were entitled to have the apartments; it was as simple as that. They were also happy that it did not cost them anything.

Mr L. likes the idea of owning a property. "When we own the apartment is ours... Then of course it is good. More than good". He emphasizes the significance of having ownership 
rights, which allows them to sell or exchange and, importantly, to bequeath it to their children.

After becoming owners in 1998, and obtaining money from the sale of one apartment, they did quite a few upgrading works, i.e. installed a toilet, a shower, a washbasin with warm water boiler, and putting new tiles on the toilet floor and wall. At present, they have no plans to further upgrade. Mr. L. is satisfied with the apartment and sees no need for further improvement:

It's quite spacious here. There is no need to upgrade more ... The thing is that we have enough for our demand... Now it is enough for us to live in ... There is no need to do more upgrading. What can that be!

\section{The Former Textile Worker}

Mrs N. lives with her three children in an $18 \mathrm{~m}^{2}$ apartment at A3, Quynh Mai. Mrs N. started as a worker in the factory in 1975, after serving in the war. At first she got a share in a collective apartment with three other girls. When she married and had children, she obtained at first a half apartment. When the husband registered in this area, they got the whole apartment. Her husband did not work for the factory, he worked for the Post Office. He died in 1999 leaving Mrs N. alone taking care of three children.

Mrs N. is 52 years old, but she no longer works for the factory. In the late 1980s, when the factory had difficulty in getting enough assignments, she was encouraged to leave. She got some compensation money but no pension. At present, Mrs N. works as a child minder to provide for the whole family. She earns about 400000 VND per month.

Mrs N.'s children are grown up, but none of them can earn a living yet. Her first son is 29 , and is a drug addict; he was at a rehabilitation centre at the time of the interview, expected to return in 2004. The second son, 17 years old, occasionally works as a builder in her home village, when some relatives need help. He goes away for short-term jobs and returns when there are no more jobs. Her 21-year-old daughter studies at college.

She applied for the certificate at the same time with many other residents in the block but she was among those who did not get it in time before the sale stopped. Mrs N. is very disappointed and feels that the authorities have been unfair to her.

I hope the government acts with consequence. If they give certificates for some people they have to give it to the rest of us in the same situations.... They also worked like us and they got it, so why can't we get it? It is unfair.

For her, to own is an important saving. The rent is a heavy burden for her.

The most important thing is not to have to pay the rent... It is a lot of money every month. And this building is so tardy and so much degraded and it leaks here and there. Many things are in need of repair. And they wanted us to pay the rent. We have paid the rent since 1975 to recently when they said we need not pay any more. All that money! We could even buy a decent apartment with it. 
To own also means to feel more secure. To rent is to live in a dwelling that belongs to somebody else, an uncertain situation. The certificate would be a guarantee that this apartment is theirs.

Mrs N. worries about redevelopment. She fears not to be able to pay and not being able to stay. They hardly have enough to survive as it is now, she said.

How can we pay! We only want a small apartment like this, and a utility. Other people with money they can pay. For me, I don't have employment. ... We just try to make it from one meal to the next, how can we pay!

She would be happy to have an apartment of the same size but it should have its own kitchen and toilet. If they were to be relocated, she could think of moving to an area nearby. She would not want to move far away even if the new apartment was better. She would lose her income in that case.

How can we survive if we have to move far away! We have lived the whole life here. Now we only want the government to give us a utility and we are willing to stay here. We don't need a bigger apartment.

\section{Secured Owners and Insecure Tenants}

The survey shows that to own an apartment is attractive to both tenants and owners. The majority of both groups (63.3 per cent tenants and 51.7 per cent owners) consider that it provides a sense of security and stability (the Vietnamese word is an $c u$, meaning secured living, or living in peace). Other advantages of owning include credibility, freedom in use, exchange and selling and economic gains.

The interviews explain more about different aspects of owning. When some residents mention the freedom to give, sell and exchange when they own, they rather emphasise the advantage in terms of legal status, and in terms of paper work, rather than in terms of practices. While the exchange and selling of rented apartments between tenants was in practice before privatisation, the difference is that, with a proper owning certificate, owners avoid problems in formalities. 'To have a legal document' is thus an aspect of an $c u$ itself.

... it is our apartment, in our names, so if we want to transfer, buy, sell or exchange it is simpler. Not so much hassle, as is the case when the apartment is owned by the state. (Owner, 54 years old)

Before privatisation, the majority of residents already took the liberty to make changes to their apartments; therefore few see ownership as a key to more freedom in use, though they admit that as owners they face fewer problems when making changes. Older people especially appreciate having a property in their name to bequeath to their children.

Some people appreciate that owning provides them with credibility, which allows them to mortgage when they need to borrow money.

For many, to own means a clear economic gain. However, this means quite different things for different social groups. For poor and low-income people, to own means to save 
by not having to pay the rent. For those who are worried about not being able to pay the rent when they retire, to own also means financial security. For residents with capital or good income, owning means the opportunity to profit or to move upwards to better housing. Few reflect on the duties and rights connected to ownership.

It is striking to see so many residents connect ownership with security or peace of mind (an $\mathrm{cu}$ ). This has several aspects. For many people, to own is an affirmation that 'this apartment is mine'. This is of special importance in uncertain times. Since many housing areas are old, and there are numerous rumours about redevelopment and demolition, to own is for many a guarantee against coming housing changes. Many residents believe that to own ensures compensation and somewhere to live in cases of demolition, redevelopment or upgrading.

The apartment is mine after I bought it, no more worry... so if they rebuild it into a high-rise or do whatever with it they have to compensate us, so we can have somewhere to live... (Owner, 54 years old)

Many also hope that by being owners they will get better terms of compensation, or face fewer problems compared to tenants:

They probably will divide us into different categories... The paperwork would probably be faster, for example... (Owner, 52 years old)

Tenants feel insecure not knowing whether their investment in the apartments would be compensated or wasted when the block is to be demolished and rebuilt.

Of course we did [the extension], but even as we did it we did not feel peace of mind. Because, yes, when they make the upgrading or demolition, we would lose the money we have invested in this ... (Tenant, 48 years old)

It is possible to say that the main difference between owning and not owning is the feeling of security. The connection between owning and the feeling of security is probably more acute in the Vietnamese housing context, where tenants have poor legal support, little knowledge about their rights and live in a situation where decisions on housing moves and developments are made 'from above' without tenants' opinions. This is also a context of the poor administration system in which there is a lack of long-term housing plans, as well as lack of transparency in development plans.

\section{Owners Are More Satisfied}

Owners are more satisfied with their housing situation compared to tenants. The majority of owners interviewed (60 per cent) say that they are pleased with their current housing situation, while the majority of tenants (63.3 per cent) said they are not. It might be possible that property ownership and the security it brings play a role in housing satisfaction, or it is rather that the majority of owners are better off and have more resources to improve their housing situation. The level of satisfaction varies according to housing areas. In all but one area, there are more tenants than owners among those not satisfied. 


\section{No Difference Between Owners and Tenants in Housing Plans}

To have the residents invest more in their dwellings and thus improve the existing housing stock has been one of the goals of privatisation in Hanoi. It was expected that once tenants become owners they would plan to improve their apartments. However, no clear difference in evidence was found in renovation activities and housing plans between tenants and owners. There were quite a small group of owners who did renovate their apartments after privatisation. However, the majority of owners (94.2 per cent) and tenants (79.2 per cent) had already upgraded their apartments before privatisation. There are also a lower percentage of owners who plan to upgrade (15.8 per cent) compared to tenants (23.3 per cent).

The question arises whether the above indicates that to own does not have any significant influence on the residents' housing plans. As a relatively short time has elapsed since many residents bought their apartments, it is too early to say. It is possible that more upgrading activities will be planned later. The fact that many residents upgraded their apartments before privatisation may illustrate that people take care of their apartments despite the form of tenure.

\section{Nobody in Charge and the Building Deteriorates}

The study shows that the buildings have been poorly maintained both before and after privatisation. According to the residents, it is the common areas, such as staircases, ceilings and communication areas that have become worse: 65.8 per cent of tenant households and 60 per cent of owner households are critical about these aspects.

When asked whether the housing area as a whole became better or worse after privatisation, the majority of residents said that there was no change and a big group said that the situation became worse ( 34 per cent of tenants and 36 per cent of owners). Overall, there is only a small difference between the responses of owners and tenants. Within each housing area, opinions vary more.

When discussing how the blocks should be taken care of, the issue of ownership of the block emerges. The majority of residents do not know who owns the blocks. Owners say they own the apartments but are unsure about who owns the blocks. Many owners still refer to the city, the government or the housing company as the body in charge and that they need to ask permission when something needs to be done to the common parts of the blocks. Only a few residents said that the privatised block belongs to the owners collectively and are confident that they can organise themselves to take care of the blocks. However they emphasised the need for legal support, such as legislation on the rights and duties of owners towards the blocks. The idea of establishing collective organisations such as a homeowners' association to take care of the buildings is not welcomed by the majority of residents, who distrust collectivism after all the years spent in the central planned economy.

The interviews show that the majority of residents do not have much understanding about maintenance and management of residential blocks. While the majority are familiar with taking action or paying for works when something needs to be fixed, the idea of regular maintenance is foreign to many. The idea of building up a collective fund to finance maintenance and management works was met with scepticism and even protest from residents. There is also a high level of distrust towards housing companies. Several 
less affluent owners, who have purchased their apartments in order to save money through not paying the rent, find it hard to consider payment of the maintenance and management fee. There are also some very poor households, and elderly households with meagre pensions, who would not be able to pay any fee at all. These are issues that need to be dealt with very soon by the government and the housing authorities.

\section{Discussion}

The study shows several consequences of privatisation. Four main issues will be commented on below. First, privatisation contributes to strengthening existing inequality between different social groups. Second, privatisation contributes to enhancing inequality between poor and better-off housing areas and indicates a beginning of a process of residential segregation, where well-off owners are supported and move up the housing ladder, while poor households are left in difficulties. Third, privatisation does not contribute to the improvement of the residential blocks. Finally, the privatisation policy presented ownership to residents only in terms of benefits, and not in terms of responsibilities, and this created serious problems for the care of the residential blocks.

\section{Strengthen Existing Inequality}

The findings indicate that privatisation in Hanoi created unequal housing opportunities for different resident groups. The policy that focuses on supporting senior governmental staff and people who made contributions in the wars, results in the strongest social groups receiving the most subvention. Senior governmental officials, who kept high or middlehigh positions in the government hierarchy, were already well situated both financially and socially; and they gain the most from the privatisation policy. Young families and those who work in the private sector are excluded from state subvention, and there are many poor and needy among these. It can be said that the privatisation policy contributes to support the existing social hierarchy and strengthening an existing inequality.

The fact that subsidised prices are applied to all residents who live in state owned housing, regardless of their financial status or housing needs, also means further problems of equity. The privatisation policy benefits people who have capital, or who have a good income (both in the state and private sector), and who therefore have no problem paying the subsidised price. At the same time, the poor and the needy receive no support. The fact that privatisation assists the better-off to make profits from state housing, lays the foundation for residential segregation by economic class.

\section{Privatisation, Residential Mobility and the Potential of Segregation}

The study provides some indication that privatisation contributes to increased residential mobility among residents in these housing areas and in Hanoi. This is expressed by the high percentage of tenants who are newcomers, and a significant percentage of owners that are newcomers who have bought their apartments from resale. Although sale figures have been relatively modest, they have a strong potential to increase in the near future. With housing demand still high, and the market price of apartments between 80 to 100 times the subsidised price, further increases in resale can be expected. Increased resale and mobility among well-off residents could lead to a process of residential segregation where well-off 
owners move up the housing ladder, leaving the area to poor residents who have little opportunity to improve their housing situations.

While certain inequalities already exist between the housing areas, depending on whether they belong to 'strong' or 'weak' work places, privatisation brings about conditions that further enhance this inequality. The privatisation policy brings about a higher percentage of owners in better-off areas, and more tenants in poorer areas. It also contributes to a high residential mobility in poor housing areas, where better-off residents move away, leaving the areas with an even higher percentage of poor residents.

At present, several of these housing areas are to be redeveloped. Better-off residents look forward to this chance to improve their housing situation. Poorer residents worry that they will have to move since they cannot afford to pay. Moreover, once the housing areas are rebuilt or upgraded, apartment prices will increase. This would make it more difficult for low-income tenants to remain in these areas. If redevelopment policies were formulated in a similar way, such as the privatisation policy, which supports the better off and ignores the poor, the poor would be driven out of these areas to be replaced by well-off residents from elsewhere.

Redevelopment can also lead to further inequality between the areas, if it is wholly directed by market interest. Since construction firms that carry out development often prefer housing areas with clear development potential, better-off and centrally located areas would be the first to be upgraded and gentrified. Poorer, less attractive, housing areas with poorer populations would be left to further decay for many more years.

\section{Privatisation and Housing Quality}

One of the goals of privatisation in Hanoi, as stated in the official documents, is to enhance residents' engagement and investment in their housing and thus to contribute to improve the quality of the housing stock. This goal is only partly fulfilled. At the level of the individual apartments, privatisation did initiate some further upgrading activities. At the level of the blocks and the housing areas, there was no indication that privatisation brought about better housing quality. On the contrary, privatisation has led to further degradation of the blocks. Common elements, such as staircases, ceilings and communication areas, are even more neglected since privatisation due to the unclear ownership status of the blocks, and the lack of regulations and rules about the rights and duties of owners towards the blocks and the housing areas.

\section{Privatisation and Homeownership}

Privatisation of state owned housing in Hanoi has provided an opportunity for residents of the old state owned housing areas to become owners. However, the subvention policy favouring senior officials and war veterans means that it is an opportunity only for a chosen group of residents, rather than a choice for all. The policy also involves a tenure bias towards owners, who, apart from having obtained a much-desired housing security, are provided with huge financial benefits. The remaining tenants are clearly in a less favourable position, having to shoulder a higher rent compared to the time before privatisation, as well as having no clear legal protection for housing security. Poor, lowincome tenant households and new tenants without permanent resident status are in very vulnerable situations. 
The study also shows that the sale of individual apartments and the lack of an adequate legal framework for ownership of residential blocks has brought about a situation of confusion and chaos, and has resulted in serious managerial problems and further neglect of the blocks.

Privatisation in this case only marks the withdrawal of the government in the care of these housing areas. It has not been a transfer from one owner to another. For the blocks, no new official owners have been specified. If this situation persists, it would be disastrous for the quality of the housing stock and negatively affect the housing conditions of the residents. In this situation, the municipal housing authority is facing two urgent tasks: first, to develop legislation on ownership of residential blocks and second, to find a model of management for housing areas with mixed ownership.

The study indicates a positive view of the residents with regard to homeownership. However, it also shows that the majority of residents believe ownership to be associated with rights and benefits, rather than duties and responsibilities, especially responsibilities towards the block. The emphasis on ownership as a means to enhance citizen involvement in housing, as promoted in the privatisation discourse in Hanoi, can be said to be generally unsuccessful when it does not lead to more residential engagement and better care of the blocks by the residents.

In terms of the goals of privatisation, it is positive that most residents like the idea of ownership and they feel more secure if they own. However, they also need to be aware of the responsibilities connected with ownership. They also need guidance and a good legal framework to support them to take care of the blocks. Sales of apartments need to be supported by a set of legislation specifying the rights and duties of owners towards the blocks. It should also be a requirement that, upon the sale, a legal body or several legal bodies (this could be professional companies or some form of residential organisation) should be identified and specified to take on the responsibility to manage and maintain the blocks after privatisation.

The study also shows that the level of knowledge about management and maintenance of residential blocks is low, both at the housing authority level and among the residents. Education and training about management of residential blocks will be necessary both for the staff at the housing authorities, as well as for the residents.

\section{Acknowledgements}

The authors acknowledge the support of the Swedish International Development Authority (SIDA) that funded the research upon which this paper draws. The authors would like to thank Julian Carey for advice on the language and her editing work. The authors are also grateful for the comments made by three referees on an earlier version of the paper.

\section{Notes}

${ }^{1}$ In Vietnam the state still has not found a way to register and control income. It is difficult to know the exact amount of people's income. Most people, even state employees, take on extra work and have several incomes other than their official employment.

${ }^{2}$ Apartments on the lower floors are more expensive than those on the upper floor. The most expensive are apartments on the ground floor, which are worth up to 1 billion VND.

3 These include retired people with state pensions, people who have other forms of state payment for previous work or war veterans who get a state payment. 
4 Those who have made 'contributions to the revolution' but do not have an employment history get a discount of 1 million VND off the house/apartment price.

5 It is required that tenants have to be registered in the area to be able to buy their apartments.

\section{References}

Chan, K. W. (2000) Prosperity or inequality: deconstructing the myth of home ownership in Hong Kong, Housing Studies, 15, pp. 29-44.

Clapham, D. (1995) Privatisation and the East European housing model, Urban Studies, 32, pp. 679-694.

Gurney, C. M. (1999) Pride and prejudice: discourse of normalisation in public and private accounts of home ownership, Housing Studies, 14, pp. 163-183.

Jaffe, A., Turner, B. \& Victorin, A. (1995) Property Rights and Privatisation in the Baltic Countries (Köpenhamn: Nordisk Ministerråd).

Japan Bank for International Co-operation (1999) Urban development and housing sector in Vietnam, JBIC Research Paper No. 3 (Research Institute for Development and Finance).

King, P. (1996) The Limits of Housing Policy, A Philosophical Investigation (Middlesex University Press).

La Grange, A. (1998) Privatising public housing in Hong Kong: its impacts on equity, Housing Studies, 13, pp. $507-525$.

Lee, J. (2000) From welfare housing to home ownership: the dilemma of China's housing reform, Housing Studies, 15, pp. 61-67.

Linneman, P. D. \& Megbolugbe, I. (1994) Privatisation and housing policy, Urban Studies, 31, pp. 635-651.

Logan, J. R., Bian, Y. \& Bian, F. (1999) Housing inequality in urban China in the 1990s, International Journal of Urban and Regional Research, 23, pp. 7-25.

Mandíc, S. (2001) Residential mobility versus 'in-place' adjustments in Slovenia: viewpoint from a society 'in transition', Housing Studies, 16, pp. 53-73.

People's Committee of Hanoi (1999) Bao cao Ket qua Ban nha theo Nghi Dinh 61 CP (Report on the sale of state owned housing following the Decree 61/CP), Hanoi, Department of Land and Housing Management, working report, unpublished.

Schlyter, A. (2002) Empowered with Ownership: The Privatisation of Housing in Lusaka (Zambia: Institute of Southern African Studies).

Stanovnik, T. (1994) The sale of the social housing stock in Slovenia-what happened and why, Urban Studies, 31, pp. $1559-1570$.

Sýkora, L. (1999) Processes of socio-spatial differentiation in post-communist Prague, Housing Studies, 14, pp. 679-701.

Zhang, X. Q. (1999) The impact of housing privatisation in China, Environment and Planning B: Planning and Design, 26, pp. 593-604.

Zhao, Y. \& Bourassa, S. C. (2003) China's urban housing reform: recent achievements and new inequities, Housing Studies, 18, pp. 721-744.

Zhou, M. \& Logan, J. R. (1996) Market transition and the commodification of housing in urban China, International Journal of Urban and Regional Research, 20, pp. 400-421. 